\title{
Zircon Xenocryst Resorption and Magmatic Regrowth at El Chichón Volcano, Chiapas, Mexico
}

Brenda Pack $^{\mathrm{a}}$, Axel K. Schmitt ${ }^{\mathrm{a}, \mathrm{b}}$, Julie Roberge ${ }^{\mathrm{c}}$, Felipe Garcia Tenorio ${ }^{\mathrm{d}}$, Brian N. Damiata ${ }^{\mathrm{e}}$

${ }^{a}$ Department of Earth, Planetary, and Space Sciences, University of California Los Angeles, Los Angeles, CA 90095, USA, pack.brenda1012@gmail.com

${ }^{\mathrm{b}}$ current address: Institut für Geowissenschaften, Universität Heidelberg, Im Neuenheimer Feld 234-236, 69120 Heidelberg, Germany, axel.schmitt@geow.uni-heidelberg.de

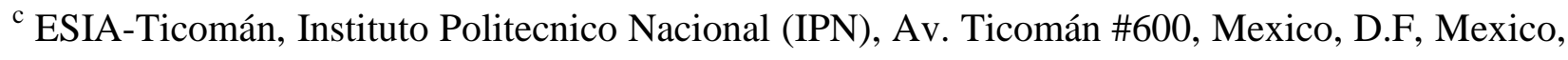
robergejulie@gmail.com

d Instituto de Geofísica, UNAM Campus Morelia, 58090, Michoacán, Mexico, felizta@hotmail.com

${ }^{\mathrm{e}}$ Cotsen Institute of Archaeology, University of California Los Angeles, 308 Charles E Young Drive West, Los Angeles, CA 90024, USA, damiata@ucla.edu

\begin{abstract}
El Chichón volcano is the only active volcano located within the Chiapanecan Volcanic Arc in southern Mexico, which lies between the Trans-Mexican Volcanic Belt and the Central American Volcanic Arc. Previous studies have shown that $~ 12$ eruptions have occurred at El Chichón within the last 8000 years, forming a complex of lava domes with a central crater and surrounding pyroclastic deposits. Here, we report the discovery of zircon in Holocene El Chichón rocks, which were analyzed by high spatial resolution imaging (color
\end{abstract}


cathodoluminescence CCL) and isotopic (secondary ionization mass spectrometry SIMS) methods to resolve core and rim crystallization ages. Pumice samples from five proximal pyroclastic flow and fall-out deposits were collected based on published stratigraphy. Two of the samples were further (re-)classified by new ${ }^{14} \mathrm{C}$ dates. In addition, we sampled two lavas from the 1982 eruption and from remnants of the older Somma lava complex. Zircon crystals were dated using ${ }^{230} \mathrm{Th} /{ }^{238} \mathrm{U}$ disequilibrium (U-Th) and U-Pb geochronology. U-Th zircon ages fall between near eruption ages and ca. $84 \mathrm{ka}$, with overlapping ages in all samples. By contrast, zircon core $\mathrm{U}-\mathrm{Pb}$ ages range between ca. $290 \mathrm{Ma}$ and $1.9 \mathrm{Ga}$. These ages are consistent with xenocrystic origins and their heterogeneity indicates derivation from clastic country rocks. Strong age contrasts between inherited xenocrystic and young magmatic domains in individual zircon crystals are evidence for arrested assimilation of crustal rocks where initially zirconundersaturated magmas cooled rapidly to form a crystal mush or subsolidus amalgamate as a crustally contaminated boundary layer. This layer contributed zircon crystals to eruptible magma during episodic recharge events followed by partial melt extraction, mixing and homogenization. Zircon overgrowths are significantly older than major minerals whose U-series ages and sharp zonation boundaries suggest crystallization only within a few ka before eruption. This implies that zircon can detect magmatic longevity which is obscured in the major mineral record.

\section{Key words}

Crustal Assimilation; Magma Chamber; Cathodoluminescence; SIMS; Geochronology; Volcanic Arc

\section{Introduction}


The volcanic eruption of El Chichón volcano (Chiapas, Mexico) in March 1982 was one of the most catastrophic volcanic disasters in the $20^{\text {th }}$ century. When it awoke, venting of trachyandesitic magma generated pyroclastic flows, ash-falls, debris flows, and surges coeval with the explosive disintegration of an $\sim 1 \mathrm{~km}$ diameter central dome (Rose et al., 1984). Ultimately, the eruption generated a new crater within an older depression whose prominent topographic margin is known as the Somma rim (Rose et al., 1984). Distal tephra falls were deposited northeast of the volcano by tropospheric and stratospheric transport (Varekamp et al., 1984). In addition, ash particles and volatiles, specifically sulfurous species, formed a concentrated aerosol cloud in the stratosphere that was detectable for 21 days (Matson, 1984). Prior to the 1982 eruption, little was known about the volcano, but because the eruption affected many lives, caused severe casualties (approximately 2000 deaths; De la Cruz-Reyna and Martin Del Pozzo, 2009), and produced local and global environmental impacts, El Chichón has garnered a reputation as an extremely hazardous volcano, and has become the focus of intense study (Scolamacchia and Capra, 2015, and references therein).

The 1982 El Chichón eruption has been recognized as an example where compositionally and isotopically evolved magma resides in the shallow crust, and reactivates prior to eruption due to recharge with more primitive magma (e.g., Davidson and Tepley, 1997; Tepley et al., 2000; Davidson et al., 2001; Andrews et al., 2008). Zoned plagioclase has systematically high ${ }^{87} \mathrm{Sr} /{ }^{86} \mathrm{Sr}$ in crystal interiors suggesting crustal assimilation during shallow magma storage, whereas rims are lower in ${ }^{87} \mathrm{Sr} /{ }^{86} \mathrm{Sr}$ indicative of recharge and mixing with more primitive magma (Davidson and Tepley, 1997; Tepley et al., 2000; Davidson et al., 2001; Andrews et al., 2008). Interaction between deep and shallow magma reservoirs is also supported by trends in seismicity during the eruption: seismic foci migrated downwards (from $\sim 2 \mathrm{~km}$ to $\sim 15 \mathrm{~km}$ ) 
indicating a transition from events directly associated with migration of magma and magma ground water interaction at shallow depth to regional tectonic strain in the wake of the eruption (Havskov et al., 1983). Despite this evidence for shallow magma storage, recharge, mixing and hybridization, the timescales and processes of magma residence at shallow levels remain poorly constrained for El Chichón. Eruptive recurrence intervals at El Chichón are brief (100-600 year; Tilling et al., 1984), and timescales of crystallization of major minerals are within a few 1000's years based on a ca. $1.3 \mathrm{ka} \mathrm{U}$-Th isochron for groundmass and plagioclase, hornblende, augite, titanomagnetite, and anhydride (Pickett et al., 1993). Despite the longevity of volcanism at El Chichón (dating back to ca. $372 \mathrm{ka}$ based on ${ }^{40} \mathrm{Ar} /{ }^{39} \mathrm{Ar}$ ages for accidental lithics; Layer et al., 2009), the 1982 eruption therefore appears to have tapped magma which shared little to none crystal heritage with its precursors, and was stored only briefly in an ephemeral magma reservoir (Tepley et al., 2000).

Zircon, a ubiquitous accessory mineral found in intermediate and evolved magmatic rocks, can be used to date crystallization in evolved melts (e.g., Schmitt 2011). Because of zircon's low solubility in such melts and its extreme retentivity for geochronologically important elements, it distinctively can trace crustal assimilation and crystal recycling (e.g., Watson, 1996). Zircon also exerts significant control over the chemical properties of magmas. Multiple detailed petrographic studies have been carried out on 1982 and older El Chichón rocks (e.g., Juvigne, 1983; Luhr et al., 1984; Rose et al., 1984; Macias et al., 2003; Arce et al., 2014; 2015). None of these studies mentioned zircon, seemingly precluding the use of zircon as a quantitative indicator for crystal storage in the subvolcanic plumbing system of continental arc volcanoes (e.g., Bacon et al., 2000; Bacon and Lowenstern, 2005; Claiborne et al., 2010; Walker et al., 2010; Stelten and Cooper, 2012; Klemetti et al., 2014; Schmitt et al., 2014). Here, we report the discovery of 
zircon crystals in heavy mineral separates from El Chichón rocks. Zircon crystals were investigated by electron beam imaging methods, including color cathodoluminescence (CCL) and distinct crystal domains visible in CCL were dated by U-Th and U-Pb methods. We demonstrate that interior domains indicate incomplete assimilation of crustal rocks, followed by overgrowth of zircon in a late Pleistocene to Holocene intrusive complex from which zircon was recycled prior to eruption.

\section{Regional geological setting}

El Chichón volcano, located in the Chiapas state of southern Mexico, comprises a trachyandesitic tuff cone and lava dome complex (Fig. 1). The volcano has been difficult to access in the past due to its remoteness, dense vegetation and rugged topography (Müllerried, 1932). It is the only active volcano in the Chiapanecan arc, and it is situated in an unusual location $400 \mathrm{~km}$ from the Central American Trench and $\sim 300 \mathrm{~km}$ above the subducted Cocos slab (Pardo and Suarez, 1995; Rebollar et al., 1999; García-Palomo et al., 2004). Competing scenarios for the origin of El Chichón magmatism are discussed in the literature: east-dipping subduction of the Cocos plate underneath the North American plate at the Central American Trench (Luhr et al., 1984, García-Palomo et al., 2004), devolatilization of the serpentinized Tehuantepec ridge (Manea and Manea, 2008), or extension and decompression melting, possibly with contributions of metasomatised mantle from former west-dipping subduction of the Yucatan plate (Kim et al., 2011; Arce et al., 2014).

Following the 1982 eruption, significant effort has been invested in establishing the chronostratigraphy of El Chichón. Here, we use the nomenclature of Espindola et al. (2000), which has been firmly established in the literature (e.g., Layer et al., 2009; Arce et al., 2014; 
2015; Scolamacchia and Capra, 2015). The base unit O from Espindola et al. (2000) consists of porphyritic trachyandesitics rocks cropping out along the margins of a 2-km wide central collapse structure (Somma) which is concentric with the smaller 1982 crater. The Somma lavas were dated by K-Ar techniques to $209 \pm 19 \mathrm{ka}$ and $276 \pm 6 \mathrm{ka}$ (ages cited in Espindola et al., 2000), but Holocene lavas also exist along the Somma rim (Layer et al., 2009). Pre-somma lavas ( $372 \pm 5$ ka) have thus far only been detected as accidental clasts (Layer et al., 2009). The oldest pyroclastic unit, N, comprises block and ash flow deposits which are locally overlain by Unit M, a porphyritic, andesitic lava flow rich in plagioclase and hornblende phenocrysts. Units $\mathrm{L}, \mathrm{K}$, and I consist of matrix-supported ash flow deposits with gravel-size andesitic clasts. Two distinctive deposits of surge and block-and-ash flow deposits make up intercalated unit $\mathbf{J}$ where abundant carbonized logs have yielded an age of $3105 \pm 70 \mathrm{BP}$ (this and other ${ }^{14} \mathrm{C}$ ages cited from Espindola et al., 2000). Unit $\mathrm{H}$, at approximately $2500 \mathrm{BP}$, is composed of six stratified beds rich in accretionary lapilli. Units $\mathrm{G}$ consists of surge beds, whereas the unit above, $\mathrm{F}$, is an ash flow deposit found only on the western side of the crater. It is separated from Unit $\mathrm{G}$ by a paleosoil, dated at $1650-1790 \mathrm{BP}$, and its depositional age of $1600 \mathrm{BP}$ is based on rounding of several ${ }^{14} \mathrm{C}$ ages for charred tree trunks. Unit $\mathrm{E}$ is a homogenous block and ash flow deposit ( $\sim \mathrm{m}$ thick) with sand-sized matrix and gravel-to boulder-sized lithic clasts. In another location, Unit E directly overlies Unit I deposits, and branches from carbonized logs at different locations yielded overlapping radiocarbon ages of $\sim 1500 \mathrm{BP}$. Unit $\mathrm{D}$, from the base up, consists of silt-sized surge beds, followed by flow deposits with a total thickness of about $5 \mathrm{~m}$. It is associated with archaeological artifacts (pottery, obsidian), and its rounded ${ }^{14} \mathrm{C}$ age is $1250 \mathrm{BP}$. Unit $\mathrm{C}$ has variable thickness, ranging from 1 to $15 \mathrm{~m}$, and is composed of pumice flow deposits near the El Platanar gully and the area to the north of the crater. The paleosoil developed on top of Unit C 
yielded an age of $795 \pm 50 \mathrm{BP}$ and separates Unit $\mathrm{C}$ from Unit B, which can be identified as a characteristically yellow pumice fallout deposit where associated charcoal samples yielded radiocarbon ages from 550 to $700 \mathrm{BP}$. Outcrops of Unit B are poorly preserved, with most exposures to the southeast of the crater. Lastly, the youngest Unit A comprises the fallout overlain by pyroclastic flow and surge deposits from the 1982 eruption. The initial explosive phase destroyed the preexisiting lava dome, and the subsequent eruptions led to the formation of pyroclastic flows and surges extending as far as approximately $8 \mathrm{~km}$ from the vent. Young dome lavas are also exposed within the 1982 crater.

\section{Materials and methods}

Seven rock samples from El Chichón volcano were obtained for a reconnaissance study of zircon internal textures and ages (Fig. 1; Supplementary Fig. 1). Samples were selected based on the stratigraphy in Espindola et al. (2000), but two deposits in the El Platanar gorge were redated by ${ }^{14} \mathrm{C}$ methods using charcoal collected adjacent to the pumice used for zircon extraction (Table 1). We concentrated on the Holocene eruption phase, targeting the most recent (Units A and $\mathrm{B}$ ) and some accessible older units (Units D and E, although the sample from Unit D was subsequently identified by ${ }^{14} \mathrm{C}$ dating as part of Unit E; Table 1). Pyroclastic deposits were sampled by collecting juvenile pumiceous materials from proximal pyroclastic flow deposits exposed in the El Platanar gorge (CH14-01, -02, -04, and -08), and a more distal (ca. $8 \mathrm{~km}$ from the vent) fall-out deposit near the village of Chapultenango (CH14-09). Two additional samples were from lavas; one from the bottom of the $\mathrm{E}$ wall of the 1982 crater $(\mathrm{CH} 14-05)$, one from the $\mathrm{E}$ Somma rim (CH14-06). 
Samples (ca. 0.5 to $2 \mathrm{~kg}$ ) were crushed, sieved into four fractions ( $<63 \mu \mathrm{m}, 63-96 \mu \mathrm{m}, 96$ - $250 \mu \mathrm{m},>250 \mu \mathrm{m}$ ), washed with water to remove clay-sized grains, and rinsed with acetone to expedite drying. Individual size fractions were panned using a pristine commercial plastic pan for gold panning filled with water and a small amount of dish detergent to mechanically separate the heavy and light minerals. Zircon crystals ranging in size between 96 and $250 \mu \mathrm{m}$ were further separated from the magnetic (which was extracted with a hand-magnet) and the light fractions (which floated after immersion in diiodomethane with a nominal density of $3.3 \mathrm{~g} / \mathrm{cm}^{3}$ ).

Twelve to fifteen individual grains from each sample were subsequently hand-picked and placed in rows onto double-coated polyimide tape glued flat onto an Al plate. In addition, AS3 zircon reference grains were added. A $~ 25 \mathrm{~mm}$ inner diameter teflon mold was placed on top of the tape with the zircon grains, and then filled with Buehler Epoxicure resin. After the epoxy was cured overnight, the mount was removed from the mold and its back lathed to a thickness of $\sim 5$ $\mathrm{mm}$. The mount was then polished using 1200 grit $\mathrm{SiC}$ paper and $1 \mu \mathrm{m}$ water-based microdiamond solution. Color cathodoluminescence (CCL) images were acquired using a TESCAN Vega XMU scanning electron microscope (SEM) at University of California Los Angeles (UCLA). CCL imaging was carried out on uncoated samples in environmental mode using a "rainbow" CL detector with a collection band-width from 350 to $850 \mathrm{~nm}$ subdivided into three channels (Fig. 2; Supplementary Figures 2-8). After imaging the mounts, they were cleaned using an ultrasonic bath and detergent, immersed into $\sim 1 \mathrm{~N} \mathrm{HCl}$, and rinsed with deionized $\mathrm{H}_{2} \mathrm{O}$ and ultimately methanol. An approximately $20-30 \mathrm{~nm}$ thick Au-coating was applied to the dried mount.

U-Th isotope analyses (Table 2) were made using a CAMECA ims1270 ion microprobe at UCLA following analyses techniques described in Reid et al. (1997) and Schmitt (2011) with 
the modification that multi-collection using three electron multipliers was applied. This allowed the simultaneous detection of mass/charge 244 (background), $246\left({ }^{230} \mathrm{ThO}^{+}\right)$and ${ }^{238} \mathrm{UO}^{+}$, reducing the duty cycle of the analyses by ca. $30 \%$. U-Th analysis of zircon interiors visible by pink vs. blue CCL activity indicated that these domains were in secular equilibrium (i.e., >380 ka, but otherwise with an undefined age). The same interior domains and others with similar CCL appearance were subsequently analyzed for their $\mathrm{U}-\mathrm{Pb}$ isotopic ages (Table 3 ) using the CAMECA ims 1270 ion microprobe at UCLA and methods described in Schmitt et al. (2003). A total of 22 xenocrystic cores were targeted to obtain $\mathrm{U}-\mathrm{Pb}$ ages. All data were reduced using ZIPS v. 3.0.4. (developed at UCLA by C. Coath). U-Th model ages were calculated using whole rock compositions from Pickett and Murrell (1997). Because their analyses of four different El Chichón units are indistinguishable within uncertainty, the average and standard deviation of these analyses were used for the melt composition. No significant difference exists between U/Th in El Chichón glass and whole rock ( 0.3; Luhr et al., 1984), further supporting the choice of the whole rock average as representative for the melt.

Charcoal samples CH14-01 and CH14-02 were pretreated at the Keck Carbon Cycle accelerator mass spectrometry (AMS) facility, University of California, Irvine. The procedure to convert raw samples into graphite targets for AMS dating involved removal of macroscopic contaminants, chemical cleaning, combustion and graphitization. The samples were subjected to an Acid-Base-Acid (ABA) chemical cleaning to remove humic and fulvic acids (Olsson, 1986). The procedure involved application of approximately $6 \mathrm{~mL}$ of $1 \mathrm{~N} \mathrm{HCl}$ for 30 minutes, followed by $1 \mathrm{~N} \mathrm{NaOH}$ for at least 30 minutes and then $1 \mathrm{~N} \mathrm{HCl}$ for another 30 minutes, all at temperatures between 70 to $90{ }^{\circ} \mathrm{C}$. The samples were then neutralized with deionized water. Intermediate application of the base solution was repeated until a clear or slightly tan liquid 
appeared. Samples CH14-01 and CH14-02 required 15 and 20 rinses, respectively, indicating that they contained moderate to high amounts of humic and fulvic acids (i.e., either as part of the original sample or acquired post-depositionally). Incomplete removal of fulvic and humic acids during the pretreatment process could result in bias towards a more recent age. Approximately 2 mg of dried sample were then placed in a quartz tube along with cupric oxide to provide an oxygen source, plus silver wire to "getter" any impurities that may adversely impact the graphitization process. The tubes were sealed under vacuum using a gas torch and then combusted at $900{ }^{\circ} \mathrm{C}$ for 3 hours to generate $\mathrm{CO}_{2}$ gas. The tubes were then placed on a vacuum line and the gaseous samples were cryogenically moved to vials containing an iron-powder catalyst. The gaseous samples were converted into graphite via the hydrogen-reduction method by heating to $500{ }^{\circ} \mathrm{C}$ for 3 hours. The graphite was then packed into aluminum sample pellets and analyzed by the AMS spectrometer. In addition, aliquots of the gaseous samples were collected from the vacuum line and analyzed separately for carbon stable isotopes using a Fisons NA-1500NC elemental analyzer equipped with a Delta-Plus IRMS stable-isotope mass spectrometer.

\section{Results}

${ }^{14} \mathrm{C}$ charcoal

Samples CH14-01 and CH14-02 yielded stratigraphically consistent ${ }^{14} \mathrm{C}$ charcoal ages of $1585 \pm 15 \mathrm{BP}$ and $535 \pm 15 \mathrm{BP}$. Calibrated ages are stated in Table 1, but for stratigraphic correlation we only use the uncalibrated ${ }^{14} \mathrm{C}$ age $\mathrm{BP}$ as was done in previous studies (Espindola et al., 2000). Based on our AMS ${ }^{14} \mathrm{C}$ results, we assign sample $\mathrm{CH} 14-02$ to the penultimate eruption of El Chichón (Unit B at 550 BP; Espindola et al. 2000). CH14-02 is thus a proximal 
equivalent to the yellow pumice fall-out of the $550 \mathrm{BP}$ eruption (CH14-09). Although analytically consistent with published ${ }^{14} \mathrm{C}$ ages, there is disagreement between our new chronostratigraphic results and the stratigraphic sections published for the head of El Platanar gorge where we collected our samples (section 97a and Fig. 8 in Espindola et al., 2000). According to these workers, Unit B should only be present as a thin $(<0.5 \mathrm{~m})$ layer, whereas our sampling location for CH14-02 near the present stream level should be in Unit C based on comparison with Espindola et al. (2000; their Fig. 8; cf. Supplementary Fig. 1). Instead it yielded a younger age implicating it as belonging to Unit B. The location where CH14-01 was collected (Supplementary Fig. 1) has been mapped as Unit D with a rounded age of 1250 BP, but our age is more similar to the rounded $1600 \mathrm{BP}$ age for Unit F (Espindola et al., 2000). Published ${ }^{14} \mathrm{C}$ ages for units E and F, however, overlap, and we thus tentatively attribute CH14-01 to Unit E which has been previously mapped in other sections of El Platanar gorge (Espindola et al. 2000). CH14-04 was not directly dated at the sampling location, but based on the published stratigraphy, we also assign it to Unit E. No ambiguities exist regarding the yellow pumice fall-out of Unit B (CH0409) and the 1982 deposit (Unit A; CH0408) which cap all other units.

\section{U-Th and U-Pb zircon geochronology}

Electron beam imaging of polished zircon interiors often revealed zonation with interior domains that are pink in CCL images, contrasting with more blueish CCL colors for the rims (Fig. 2). The presence of these zonations guided placement of SIMS analysis spots, and (after the exclusively xenocrystic nature of the pink cores was recognized) the choice of U-Th vs. U-Pb dating methods (Supplementary Figures 2-8). We also performed reconnaissance rare earth element (REE) analyses on a single representative crystal (Fig. 2). The data indicate higher 
abundances for the mid REE (by a factor of $\sim 6$ for $\mathrm{Sm}$ ) for the pink xenocrystic zircon interiors compared to the blue late Pleistocene rims (Fig. 2). The exception is Eu which shows a stronger negative anomaly in the xenocrystic interior compared to the younger magmatic rim. More blueish CCL activity in REE-poorer zircons qualitatively agrees with findings in Belousova et al. (1998).

U-Th zircon data for all Holocene Chichón samples populate a widespread range in isotopic compositions in the U-Th isochron diagram (Fig. 3). Model isochrons are based on the average of four whole rock compositions for El Chichón reported by Pickett and Murell (1997) as the anchoring point. El Chichón U-Th whole rock compositions show minor variability which is propagated (as 1 standard deviation) into the uncertainties for the U-Th zircon model ages. The consistency of many near-zero model ages with a Holocene eruption age also supports the choice of the average U-Th whole rock composition.

For the 1982 lava sample (CH14-05), the youngest zircon age is 18.5+6.8/-6.4 ka while the oldest is $84.1+15.5 /-13.5 \mathrm{ka}$ (Table 2 ). There are additional analyses with measurement uncertainties overlapping secular equilibrium, such as grain 12 with an apparent age of $422+\infty /-$ $131 \mathrm{ka}$ (secular equilibrium indicated by the infinity symbol $\infty$; Table 2). The same crystal has a significantly younger rim (41.9+7.1/-6.6 ka; Fig. 3), and the interior was subsequently dated by $\mathrm{U}-\mathrm{Pb}$ and identified as xenocrystic (Fig. 4). The apparent age of $422+\infty /-131 \mathrm{ka}$ is thus geologically not meaningful, and it reflects secular equilibrium (within analytical error). Similar observations hold for the other samples. The pumice sample from the 1982 eruption, CH14-08, has ages ranging from $9.3 \pm 2.7 \mathrm{ka}$ to $60.9+7.6 /-7.1 \mathrm{ka}$ (Table 2). Again, there are several analyses that are indistinguishable from secular equilibrium within uncertainty which were confirmed as xenocrystic (Fig. 4). Zircon ages for sample CH14-02 (identified as the 550 BP Unit B) range 
between $3.7+5.3 /-5.1 \mathrm{ka}$ and $46.9+6.0 /-5.7 \mathrm{ka}$. This is similar to the stratigraphically equivalent sample $\mathrm{CH} 14-09$ (yellow pumice from the Unit B distal fall-out deposit) where ages range between $5.8+4.7 /-4.5 \mathrm{ka}$ and $60.9+6.8 /-6.4 \mathrm{ka}$ (excluding analyses that are analytically indistinguishable from secular equilibrium). CH14-04 is from a pyroclastic flow unit (Unit E; nominal ${ }^{14} \mathrm{C}$ age $1500 \mathrm{BP}$; Espindola et al., 2000) which directly underlies the 1982 deposit. Zircon crystals from $\mathrm{CH} 14-04$ yielded U-Th ages that range from $2.8+11.5 /-10.4$ ka to 60.7 $+13.3 /-11.8 \mathrm{ka}$. On average, younger crystals are more abundant in CH14-04 compared to the overlying deposit, although in both cases zircon crystals are much older than the eruptions ages. Sample CH14-01 (Unit E), which underlies CH14-02 (Unit B), has zircon ages ranging from 0.2 +4.0/-3.9 ka to 82.9 +20.3/-17.1 ka. Somma lava (CH14-06) has an unknown eruption age, but based on zircon ages between $13.5+8.6 /-8.0 \mathrm{ka}$ and $37.8+7.1 /-6.7 \mathrm{ka}$ it is clearly younger than Somma lavas dated to $209 \pm 19 \mathrm{ka}$ and $276 \pm 6 \mathrm{ka}$ (Espindola et al., 2000). Few older core analyses are suspect because of overlap onto xenocrystic cores in secular equilibrium (e.g., CH14-06 z6).

Secular equilibrium spots determined from U-Th geochronology, as well as conspicuously pink interiors were analyzed by $\mathrm{U}-\mathrm{Pb}$ methods. These yielded ages between ca. $290 \mathrm{Ma}$ and $1.9 \mathrm{Ga}$ (Fig. 4). On a concordia diagram, most data plot near concordia showing only minor discordance. Only the oldest zircons fall on a discordia with a lower intercept of ca. $900 \mathrm{Ma}$, whereas three discordant analyses with younger (<290 Ma) apparent ages tend towards the origin, suggesting either very recent $\mathrm{Pb}$ loss, or, more likely based on post-analysis imaging of the SIMS spot locations, lateral beam overlap between interior and rim domains. Because of this, they are excluded from further discussion.

\section{Discussion}


Zircon in continental arc volcanoes

Zircon is known to be a reliable magma chronometer due to its sluggish diffusion rate for uranium and its intermediate daughters (Cherniak et al., 1997). Furthermore, it is able to record magma differentiation because it will only crystallize in comparatively evolved (and $\mathrm{Zr}$ enriched) magmas whereas hot, mafic magma will rapidly dissolve zircon (e.g., Watson, 1996; Boehnke et al., 2013). The presence of zircon predating the eruption, either as "antecrysts" which are derived from coeval plutons in the subvolcanic environment or as "xenocrysts" from the country rock, can thus be expected in evolved magmas, whereas melts that are strongly undersaturated in zircon can completely resorb preexisting zircon within several 100 years (e.g., Bacon and Lowenstern, 2005). Although dissolution timescales are rapid in undersaturated melts, antecrystic zircon, often predating the eruption by many 10's to 100's of ka, typically dominates over zircon with near-eruption in arc magmas, and these crystals are interpreted to be recycled from a largely crystalline subvolcanic magma reservoir or plutonic complex (e.g., Crater Lake: Bacon et al., 2000; Bacon and Lowenstern, 2005; Mount St. Helens: Claiborne et al., 2010; Aucanquilcha: Walker et al., 2010; South Sisters: Stelten and Cooper, 2012; Mount Lassen: Klemetti and Clynne, 2014; Hasan Dağı: Schmitt et al., 2014). Remarkably, xenocrystic zircon is rare in most continental arc volcanoes (see previous references; cf. Garrison et al., 2006) despite geochemical evidence that mantle derived magmas in these environments are inevitably crustally contaminated. The lack of xenocrystic zircon reflects that crustal assimilation is most efficient at high temperatures where zircon of country-rock provenance becomes rapidly resorbed. In this context of previous studies of zircon in continental arc volcanic rocks, two major differences emerge for El Chichón: (1) antecrystic zircon is abundant, but ages do not extend past ca. 84 ka; zircon thus lacks any evidence for recycling from the mid Pleistocene precursors of modern El 
Chichón, and (2) xenocrystic domains are present in a significant $(\sim 30 \%)$ proportion of the zircon population. The implications of these observations regarding zircon provenance in Holocene El Chichón rocks are discussed in the following.

Zircon and the timing of El Chichón magmatism

The presence of zircon in El Chichón rocks can uniquely constrain the age of the intrusive system underneath the volcano, and shed new light on the origins of evolved magma that blended into, and erupted with more mafic magma recharge (Davidson and Tepley, 1997; Tepley et al., 2000; Davidson et al., 2001; Macias et al., 2003; Andrews et al., 2008). Although the number of U-Th analyses per sample $(n=10-16)$ is too restricted to provide firm constraints on similarities and differences between individual samples, the overall ranges and major peaks in the U-Th age distribution (e.g., at ca. $10 \mathrm{ka}$ and 30-40 ka) are common to all samples (Fig. 5). With the caveat that sampling density is low, Kolmogorov-Smirnov statistics applied to zircon ages (Fletcher et al., 2006) confirms that the U-Th dated domains are mostly statistically indistinguishable between individual samples. The only exceptions are the lava samples CH14-05 (1982 crater) and $\mathrm{CH} 14-06$ (Somma lava) which are dissimilar (with a probability $\mathrm{P}<0.05$ which is the limit to reject the null hypothesis for two populations being identical), and in the case of $\mathrm{CH} 14-05$ also distinct from CH14-02 (proximal 550 BP Unit B).

From comparing the age of zircon crystallization with the time of eruption, it is obvious that the duration of magma presence under El Chichón was much more long-lived than the period of frequent eruptions documented for the mid to late Holocene (Espindola et al., 2000). The zircon age distributions ranging back to ca. 84 ka prior to eruption overlap with ${ }^{40} \mathrm{Ar} /{ }^{39} \mathrm{Ar}$ ages for accidental lithics and peripheral lava domes to the NW and SW of the Holocene edifice 
(Layer et al., 2009). Our zircon results also confirm previous ${ }^{40} \mathrm{Ar} /{ }^{39} \mathrm{Ar}$ results (Layer et al., 2009; cf. Damon and Montesinos, 1978; Duffield et al., 1984), and indicate that Somma lavas are in part younger than ca. $20 \mathrm{ka}$. Older ${ }^{40} \mathrm{Ar} /{ }^{39} \mathrm{Ar}$ ages (up to $372 \pm 5 \mathrm{ka}$; Layer et al., 2009), however, are not represented in the zircon age population (Fig. 6).

Collectively, the homogeneity of zircon ages suggest that all sampled units with eruption ages between ca. 1600 BP (Table 1) and 1982 tapped the same magma system containing zircons that have crystallized over several 10's of ka. The youngest crystals have ages that are analytically indistinguishable from the eruption age, but we emphasize that because zircon crystals were analyzed in cross-sections through crystal interiors, the outermost crystal rims could not be analyzed without contribution from older zircon mantles. This means that the youngest ages reported here are likely upper limits for the youngest phase of zircon crystallization. Absence of zircon from the Pleistocene (>84 ka) activity of El Chichón's precursors (e.g., the older part of the Somma volcano) is intriguing. With the caveat that some mixing between zircon domains of different age is possible, we argue that the lack of antecrystic zircon significantly older than ca. $84 \mathrm{ka}$ is robust because sectioning will preferentially expose the surface of early formed zircon interiors (e.g., Samperton et al., 2015). The reasons for the absence of older antecrysts remain speculative because we only concentrated on the Holocene eruption phase, and it remains to be demonstrated if zircon is present in Pleistocene El Chichón rocks. Moreover, published eruption ages are based on K-Ar and Ar-Ar measurements with the possibility that unsupported ${ }^{40} \mathrm{Ar}$ could lead to overestimation of the eruption ages.

Zircon xenocrysts: provenance and resorption 
Zircon xenocryst survival from assimilated country rocks is ubiquitous in Holocene El Chichón magmas. Xenocrysts are often identified as distinct CCL pink domains with rounded boundaries against CCL blue domains, and truncated interior oscillatory zonation. Where analyzed, these cores were found to be in secular equilibrium for $\left({ }^{230} \mathrm{Th}\right) /\left({ }^{238} \mathrm{U}\right)$, in contrast to CCL blue overgrowth which show disequilibrium. U-Pb dating of these secular equilibrium domains yielded ages that predate the El Chichón magma system (Fig. 6). The presence of xenocrystic domains is consistent with isotopic disequilibrium in El Chichón magmas which is also evident from isotopically zoned plagioclase where high ${ }^{87} \mathrm{Sr} /{ }^{86} \mathrm{Sr}$ cores are overgrown by low ${ }^{87} \mathrm{Sr} /{ }^{86} \mathrm{Sr}$ rims (Davidson and Tepley, 1997; Tepley et al., 2000; Davidson et al., 2001; Andrews et al., 2008). Zircon xenocrystic cores can provide additional constraints on the nature of the crustal contaminant involved: their age distribution closely matches those of metasedimentary and metaigneous crystalline rocks of the Chiapas Massif Complex (Weber et al., 2008; 2009). One possible explanation for the provenance of xenocrystic zircons is thus that sediments underlying El Chichón carry zircons derived from basement in the highlands to the $\mathrm{SW}$. This interpretation is supported by the mix of ages in the zircon cores which suggests that the assimilated source rocks already contained mixed zircon populations. These interpretations are tentative, because of the comparatively small number of zircon xenocrysts $(n=22)$ used in this comparison; more robust statistics would be required to place these conclusions on a firm foundation.

Zircon saturation temperatures (using the calibration of Boehnke et al., 2013 and published whole rock data from Luhr et al., 1984; Varekamp et al., 1984; Rose et al., 1984; Espindola et al., 2000; Macias et al., 2003; Layer et al., 2009; Arce et al., 2014) fall well below the $\sim 800^{\circ} \mathrm{C}$ eruption temperature estimated for El Chichón trachyandesites (e.g., zircon 
saturation temperatures are $\sim 600^{\circ} \mathrm{C}$ for 1982 pumice with $\mathrm{Zr}=\sim 140 \mathrm{ppm}$; Luhr et al., 1984). This implies that the recharge magma was initially strongly zircon undersaturated and thus likely devoid of any zircon xenocrysts. However, at the time of eruption El Chichón magmas had elevated ( 25-50 vol. \%; e.g., Luhr et al., 1984; Vahrekamp et al., 1984) crystal contents, and the melt was consequently more enriched in $\mathrm{Zr}$ and had lower $\mathrm{M}$ values $(\mathrm{M}=[\mathrm{Na}+\mathrm{K}+2 \mathrm{Ca}] /[\mathrm{Al} \times$ Si]) compared to the bulk. Using the 1982 glass compositions (e.g., Luhr et al., 1984), we calculate $\mathrm{Zr}$ saturation concentrations of $365 \mathrm{ppm}\left(\right.$ at $800^{\circ} \mathrm{C}$ ) and $230 \mathrm{ppm}\left(\right.$ at $750^{\circ} \mathrm{C}$ ), compared to actual abundances of $\mathrm{Zr}=200 \mathrm{ppm}$ in the glass (inferred from glass $\mathrm{Hf}$ data in Luhr et al., 1984, and chondritic $\mathrm{Zr} / \mathrm{Hf}=38$ ). Under these moderately to mildly zircon undersaturated conditions, a xenocryst of originally $100 \mu \mathrm{m}$ would become resorbed to half its initial size over timescales of $\sim 6 \times 10^{3}\left(800^{\circ} \mathrm{C}\right)$ to $\sim 1.2 \times 10^{5}\left(750^{\circ} \mathrm{C}\right)$ years, according to the curves in Fig. 6 of Watson (1996). These timescales are maximum values that refer to the erupted trachydacite magma composition and temperature; for hotter magma recharge compositionally equivalent to rare mafic enclaves in El Chichón rocks ( $\mathrm{Zr} \sim 100$ ppm; Macias et al., 2003), undersaturation would be more severe, and resorption more rapid. Given that these timescales are commensurate to the overall duration of late Pleistocene-Holocene zircon crystallization for El Chichón, the survival of zircon xenocryst cores can only be explained if they mostly resided in near- or subsolidus "cold-storage" (Kent and Cooper, 2014), rather than in a long-lived high-temperature magmatic environment.

According to zircon dissolution models (Watson, 1996), three factors that favor zircon xenocryst survivability are large crystal dimensions in the crustal assimilant, failure of the melt to coalesce into large magma bodies, and rapid (or weak) magmatic heating pulses. The size of zircon in the El Chichón country rocks is unknown, but are unlikely to be larger than 100-200 
$\mu \mathrm{m}$ typical for most detrital zircons. The arrested resorption of El Chichón xenocrysts thus suggests that assimilation occurred in small melt volumes (possibly via extraction of locally generated anatectic melts) and fast, possibly via injection of small volumes of mafic to intermediate magma which cooled rapidly in a near-surface environment adjacent to cold country rock. Another factor that would aid zircon xenocryst survival is high $\mathrm{Zr}$ abundance in the assimilant. In fact, continental crustal averages ( 200 ppm; Rudnick and Gao, 2004) are higher compared to mafic-intermediate magma recharge for El Chichón ( 100-150 ppm; Luhr et al., 1984; Macias et al., 2003). It thus seems likely that initially undersaturated El Chichón trachydacite magma became saturated after it evolved through a combination of crustal assimilation and fractional crystallization.

\section{Zircon constraints on magmatic processes at El Chichón}

Zircon's durability and relative resistance to resorption is unlike any other magmatic crystal phase in El Chichón rocks. The internal zircon resorption and overgrowth textures are consistent with rapid thermal and/or compositional cycling, possibly in a series of recharge events. The oldest zircon crystals (barring xenocrystic cores) date back to ca. 84 ka (Fig. 6), which is younger than earlier magmatic events which formed the Pre-Somma, Somma, and peripheral domes (to the N and SW of the modern edifice; Layer et al., 2009; Scolamacchia and Capra, 2015). There is some overlap between zircon crystallization ages and eruption ages for the NW dome (Layer et al., 2009; Scolamacchia and Capra, 2015) but most zircon crystals postdate this episode of lateral dome formation (Fig. 6). Zircon U-Th ages extend down to Holocene ages activity, but show an apparent decline in the probability density distribution for ages $<8 \mathrm{ka}$. We caution, however, that the most recent zircon crystallization might have gone 
undetected because of the positioning of the analysis spots onto sectioned zircon crystals where the outermost rims of the zircons cannot be sampled without overlap onto interior domains, and that the apparent underrepresentation of Holocene zircon rims could be due to this sampling bias. This comparative longevity of zircon is in stark contrast to major phases (plagioclase, amphibole, clinopyroxene) and magnetite which collectively lack evidence for protracted crystal residence based on their U-Th isochron age of 1.3 $\pm 2.3 \mathrm{ka}$ (Pickett et al., 1993).

A frequent pattern of high ${ }^{87} \mathrm{Sr} /{ }^{86} \mathrm{Sr}(\sim 0.706)$ plagioclase cores mantled by low ${ }^{87} \mathrm{Sr} /{ }^{86} \mathrm{Sr}$ $(\sim 0.704)$ in El Chichón rocks indicates intrusion of less contaminated mafic magma into a more contaminated reservoir, or reaction of recharge magma with a crustally contaminated boundary layer (Tepley et al., 2000; Davidson et al., 2000; Davidson et al., 2001; Andrews et al., 2008). The compositional homogeneity of the erupted trachyandesites throughout El Chichón's phase of Holocene activity implies that the resulting hybrid magma reservoir was well mixed, despite isotopic heterogeneity in phenocrysts and the rare preservation of rounded mafic enclaves as witnesses for basaltic input into the system (e.g., Macias et al., 2003). Zircon adds a new aspect to this scenario in that it demonstrates that this boundary layer significantly predates the Holocene magma system, and that it selectively provided zircon (along with a chemical signal of elevated ${ }^{87} \mathrm{Sr} /{ }^{86} \mathrm{Sr}$ ) to the recharge magma (Fig. 7). Holocene eruptions then tapped this zircon reservoir which has not qualitatively changed despite multiple eruptions from 1600 BP onward, including the most recent event of 1982. Zircon xenocryst survival requires that crystals in this contaminated reservoir or boundary layer resided in a highly crystalline mush or subsolidus intrusions (e.g., Cooper and Kent, 2014) for most of their lifetime, with zircon assimilation, resorption and growth being restricted to brief episodes during ephemeral recharge and mixing events. 
The absence of evidence for major phases being coeval with zircon (at least for the 1982 eruption; Pickett et al., 1993) is intriguing, and may hint at the special role that zircon plays in magmatic differentiation: its small crystal size makes it conducive to be transported with the melt (e.g., when melt extraction occurs at low degrees of partial melting), and by the same token it resists gravitational settling upon crystallization (Reid and Coath, 2000). Moreover, slow melt diffusion of $\mathrm{Zr}$ as its major stoichiometric component aids in its preservation under conditions where major phases may not survive. In this case, major phases (specifically: plagioclase) record only the chemical signal that resulted from magma recharge causing melts with high ${ }^{87} \mathrm{Sr} /{ }^{86} \mathrm{Sr}$ to become mobilized from a contaminated boundary zone between the eruptible interior of the magma reservoir and country rock, followed by progressive dilution with low ${ }^{87} \mathrm{Sr} /{ }^{86} \mathrm{Sr}$ magma as recharge and mixing progressed (Fig. 7). In contrast to zircon, carry-over of plagioclase from the boundary layer is dismissed based on young U-Th ages (Pickett et al., 1993), and the

preservation of sharp transitions from high to low ${ }^{87} \mathrm{Sr} /{ }^{86} \mathrm{Sr}$ in plagioclase which are only permissive for brief (100's to few 1000's of years) magmatic crystal residence (Davidson et al., 2001; Andrews et al., 2008). Comparatively frequent preservation of xenocrystic zircon in El Chichón magmas relative to many other continental arc volcanoes may reflect the early stages of a subvolcanic magma reservoir where assimilation of country rocks is possible whereas established magma systems are shielded from their host rocks by a carapace of precursor intrusions.

\section{Conclusions}

Although numerous studies have been made about El Chichón volcano, zircon has not yet been described, and consequently the discovery and dating of zircon via $\mathrm{U}-\mathrm{Th}$ and $\mathrm{U}-\mathrm{Pb}$ 
geochronology is important as it provides unique insights into the El Chichón magma system.

This study specifically explores zircon ages from juvenile rocks (pumice and lava) from the 1982 eruption and selected antecedent eruptions dating back to ca. $1600 \mathrm{BP}$. U-Th isochron ages for El Chichón zircons range from late Holocene to ca. 84 ka, with hardly any resolvable differences between samples. In addition, secular equilibrium zircon domains with different properties in $\mathrm{CCL}$ are present which yielded heterogeneous $\mathrm{U}-\mathrm{Pb}$ ages consistent with detrital provenance from regional metaigneous and metasedimentary sources. The spread of zircon ages suggests that magmatic activity at El Chichón has already initiated by ca. 84 ka, but there is no evidence for zircons similar in age to ${ }^{40} \mathrm{Ar} /{ }^{39} \mathrm{Ar}$ dates for some older accidental lithics and precursor domes. During the late Pleistocene-Holocene, a subvolcanic reservoir has formed whose boundary layer of crustally contaminated intrusions exerted strong control on the isotopic properties of the Holocene El Chichón magmas. Zircon is recycled from this reservoir during ephemeral recharge events which also may have interrupted intermittent eruptive dormancy.

\section{Acknowledgements}

Alejandro Cisneros provided support during field work, and helpful comments to earlier versions of the manuscript. Adriana Camacho is thanked for assistance during field work. We also thank the editor, Malcolm Rutherford, and reviewer Erik Klemetti for their constructive comments. Support through UC-MEXUS grant CN 13-567 and the Instrumentation and Facilities Program, Division of Earth Sciences, National Science Foundation, is acknowledged.

\section{References}


Annen C, Wagner JJ. 2003. The impact of volcanic eruptions during the 1990s. Natural Hazards Review. Vol.4 Issue 4: 169-175.

Andrews BJ, Gardner JE, Housh, TB. 2008. Repeated recharge, assimilation, and hybridization in magmas erupted from El Chichón as recorded by plagioclase and amphibole phenocrysts. Journal of Volcanology and Geothermal Research, 175(4), 415-426.

Arce JL, Walker J, Keppie JD. 2014. Petrology of two contrasting Mexican volcanoes, the Chiapanecan (El Chichón) and Central American (Tacaná) volcanic belts: the result of rift- versus subduction-related volcanism. International Geology Review. Vol. 56 Issue 4:501-524.

Arce JL, Walker J, Keppie, JD. 2015. Petrology and Geochemistry of El Chichón and Tacaná: Two Active, yet Contrasting Mexican Volcanoes. In Active Volcanoes of Chiapas (Mexico): El Chichón and Tacaná (pp. 25-43). Springer Berlin Heidelberg.

Bacon CR, Persing HM, Wooden JL, Ireland TR. 2000. Late Pleistocene granodiorite beneath Crater Lake caldera, Oregon, dated by ion microprobe. Geology, 28(5), 467-470.

Bacon CR., Lowenstern JB. 2005. Late Pleistocene granodiorite source for recycled zircon and phenocrysts in rhyodacite lava at Crater Lake, Oregon. Earth and Planetary Science Letters, 233(3), 277-293.

Belousova EA, Griffin WL, Pearson NJ. 1998. Trace element composition and cathodoluminescence properties of southern African kimberlitic zircons. Mineralogical Magazine, 62(3), 355-366

Boehnke P, Watson EB, Trail D, Harrison TM, Schmitt AK. 2013. Zircon saturation re-revisited. Chemical Geology, 351, 324-334. 
Cherniak DJ, Hanchar JM, Watson, EB. 1997. Diffusion of tetravalent cations in zircon. Contributions to Mineralogy and Petrology, 127(4), 383-390.

Claiborne LL, Miller, CF, Flanagan DM, Clynne MA., Wooden JL. 2010. Zircon reveals protracted magma storage and recycling beneath Mount St. Helens. Geology, 38(11), 1011-1014.

Cooper KM, Kent AJ. 2014. Rapid remobilization of magmatic crystals kept in cold storage. Nature, 506(7489), 480-483.

Craig H, 1957. Isotopic standards for carbon and oxygen and correction factors for massspectrometric analysis of carbon dioxide. Geochimica et cosmochimica acta, 12(1), 133149

Davidson JP, Tepley FJ. 1997. Recharge in volcanic systems: evidence from isotope profiles of phenocrysts. Science, 275(5301), 826-829

Davidson J, Tepley F, Palacz Z, Meffan-Main S. 2001. Magma recharge, contamination and residence times revealed by in situ laser ablation isotopic analysis of feldspar in volcanic rocks. Earth and Planetary Science Letters, 184(2), 427-442.

Davidson JP, Morgan DJ, Charlier BL. 2007. Isotopic microsampling of magmatic rocks. Elements, 3(4), 253-259.

De la Cruz-Reyna S, Martin Del Pozzo, AL. 2009. The 1982 eruption of El Chichón volcano, Mexico: Eyewitness of the disaster. Geofísica internacional, 48(1), 21-31.

Espindola JM, Macias JL, Tilling RI, Sheridan MF. 2000. Volcanic history of El Chichón Volcano (Chiapas, Mexico) during the Holocene, and its impact on human activity. Bulletin of Volcanology. Vol. 62 Issue 2: 90-104. 
Fletcher JM, Grove G, Kimbrough D, Lovera O, Gehrels GE. 2007. Magdalena shelf and southern Gulf of California: Insights from detrital zircon U-Pb ages from the Magdalena fan and adjacent areas. GSA Bulletin. Nov./Dec. 2007. Vol. 119: 11/12: 1313-1336.

García-Palomo A, Macías JL, Espíndola JM. 2004. Strike-slip faults and K-alkaline volcanism at El Chichón volcano southeastern México. J. Volcanol. Geotherm. Res. Vol.136: 247-268.

Garrison J, Davidson J, Reid M, Turner S. 2006. Source versus differentiation controls on Useries disequilibria: insights from Cotopaxi Volcano, Ecuador. Earth and Planetary Science Letters, 244(3), 548-565.

Havskov J, De la Cruz-Reyna S, Singh SK, Medina F, Gutiérrez C. 1983. Seismic Activity Related to the March-April, 1982 Eruptions of El Chichón Volcano, Chiapas, Mexico. Geophysical Res. Letters. Vol.10, No.4: 293-296.

Ivanovich M, Harmon RS. 1992. Uranium-Series Disequilibrium: Applications to Earth, Marine, and Environmental Sciences. Oxford: Clarendon. p 910.

Kim YH, Clayton RW, Keppie F. 2011. Evidence of a collision between the Yucatán Block and Mexico in the Miocene. Geophysical Journal International. Vol. 187: 989-1000.

Klemetti EW, Clynne MA. 2014. Localized rejuvenation of a crystal mush recorded in zircon temporal and compositional variation at the Lassen Volcanic Center, northern California. PloS one, 9(12), e113157.

Layer PW, Garcia-Palomo A, Jones D, Macias JL, Arce JL, Mora JC. 2009. El Chichón volcanic complex, Chiapas, México: Stages of evolution based on field mapping and ${ }^{40} \mathrm{Ar} /{ }^{39} \mathrm{Ar}$ geochronology. Geoffis. Inter. Vol. 48 Issue 1:33-54. 
Luhr JF, Carmichael ISE, Varekamp J. 1984. The 1982 eruptions of El Chichón Volcano, Chiapas, Mexico: Mineralogy and petrology of the anhydrite-bearing pumices. $J$. Volcanol. Geotherm. Res. Vol. 23: 69-108.

Luhr JF. 1990. Experimental phase relations of water-and sulfur-saturated arc magmas and the 1982 eruptions of El Chichón volcano. Journal of Petrology, 31(5), 1071-1114.

Macías JL, Arce JL, Mora JC, Espíndola JM, Saucedo R, Manetti P. 2003. A 550-year-old Plinian eruption at El Chichón Volcano, Chiapas, Mexico: Explosive volcanism linked to reheating of the magma reservoir. Journal of Geophysical Research: Solid Earth (19782012), 108(B12).

Manea M, Manea VC. 2008. On the origin of El Chichón volcano and subduction of Tehuantepec Ridge: A geodynamical perspective. Journal of Volcanology and Geothermal Research, 175(4), 459-471.

Matson M. 1984. The 1982 El Chichón Volcano Eruptions- A Satellite Perspective. J. Volcanol. Geotherm. Res. Vol. 23: 1-10.

Pardo M, Suarez G. 1995. Shape of the subducted Rivera and Cocos Plates in southern Mexico: Seismic and tectonic implication. J. Volcanol. Geotherm. Res. Vol. 100: 12357-12373.

Pickett DA, Murrell MT, Tilling RI. 1993. U/Th and Th isotopes in minerals from El Chichón trachyandesite: implications for crystal/liquid partitioning in andesitic systems. EOS Trans. Am. Geophys. Union, 74(16), 341.

Pickett DA, Murrell MT. 1997. Observations of ${ }^{231} \mathrm{~Pa} /{ }^{235} \mathrm{U}$ disequilibrium in volcanic rocks. Earth Planet. Sci. Lett. 148: 259-271. 
Rebollar CJ, Espíndola VH, Uribe A, Mendoza A, Pérez-Vertti A. 1999. Distribution of stress and geometry of the Wadati-Benioff zone under Chiapas, Mexico. Geoffs. Inter. Vol. 38: 95-106.

Reid MR, Coath CD, Harrison TM, McKeegan KD. 1997. Prolonged residence times for the youngest rhyolites associated with Long Valley Caldera: ${ }^{230} \mathrm{Th}-{ }^{238} \mathrm{U}$ ion microprobe dating of young zircons. Earth Planet. Sci. Lett. Vol. 150: 27-39.

Rose Jr. WI, Bornhorst TJ, Halso SP, Capaul WA, Plumley PS, Cruz-Reyna SD, Mena M, Mota R. 1984. Volcán El Chichón, Mexico: Pre-1982 S-rich eruptive activity. J. Volcanol. Geotherm. Res. Vol. 23: 147-149,155-167.

Rudnick RL, Gao S. 2004. Composition of the Continental Crust. In: Treatise on Geochemistry. Holland, HD and Turekian, KK (Editors), Elsevier, Amsterdam. 3: 1-64.

Samperton KM, Schoene B, Cottle JM, Keller CB, Crowley JL, Schmitz MD. 2015. Magma emplacement, differentiation and cooling in the middle crust: Integrated zircon geochronological-geochemical constraints from the Bergell Intrusion, Central Alps. Chemical Geology, 417, 322-340.

Schmitt AK, Grove M, Harrison TM, Lovera O, Hulen J, Walters M. 2003. The Geysers-Cobb Mountain Magma System, California (Part 1): U-Pb zircon ages of volcanic rocks, conditions of zircon crystallization and magma residence times. Geochimica et Cosmochimica Acta, 67(18), 3423-3442.

Schmitt AK. 2011. Uranium Series Accessory Crystal Dating of Magmatic Processes. Annu. Rev. Earth Planet. Sci. Vol. 39: 321-349. 
Schmitt AK, Danišík M, Aydar E, Şen E, Ulusoy İ, Lovera OM. 2014. Identifying the Volcanic Eruption Depicted in a Neolithic Painting at Çatalhöyük, Central Anatolia, Turkey. PloS one, 9(1), DOI: 10.1371/journal.pone.0084711.

Scolamacchia T., Capra L. 2015. El Chichón Volcano: Eruptive History. In: Active Volcanoes of Chiapas (Mexico): El Chichón and Tacaná (pp. 45-76). Springer Berlin Heidelberg.

Stelten ME, Cooper KM. 2012. Constraints on the nature of the subvolcanic reservoir at South Sister volcano, Oregon from U-series dating combined with sub-crystal trace-element analysis of plagioclase and zircon. Earth and Planetary Science Letters, 313, 1-11.

Stuiver M, Polach HA. 1977. Discussion; reporting of C-14 data. Radiocarbon, 19(3), 355-363

Tepley FJ, Davidson JP, Tilling RI, Arth J. 2000. Magma Mixing, Recharge and Eruption Histories in Plagioclase Phenocrysts from El Chichón Volcano, Mexico. Journal of Petrology. Vol. 41: 1397-1411.

Tilling RI, Rubin M, Sigurdsson H, Carey S, Duffield WA. 1984. Prehistoric eruptive activity of El Chichón volcano, Mexico. Science. Vol. 224: 747-749.

Walker BA, Grunder AL, Wooden JL. 2010. Organization and thermal maturation of long-lived arc systems: Evidence from zircons at the Aucanquilcha volcanic cluster, northern Chile. Geology, 38(11), 1007-1010.

Watson EB. 1996. Dissolution, growth and survival of zircons during crustal fusion: kinetic principles, geological models and implications for isotopic inheritance. Geological Society of America Special Papers, 315, 43-56.

Weber B, Valencia VA, Schaaf P, Pompa-Mera V, Ruiz J. 2008. Significance of provenance ages from the Chiapas Massif Complex (southeastern Mexico): redefining the Paleozoic 
basement of the Maya Block and its evolution in a peri-Gondwanan realm. The Journal of Geology, 116(6), 619-639.

Weber B., Valencia VA, Schaaf P, Ortega-Gutiérrez F. 2009. Detrital zircon ages from the Lower Santa Rosa Formation, Chiapas: implications on regional Paleozoic stratigraphy. Revista Mexicana de Ciencias Geológicas, 26(1), 260-276.

\section{Figure Captions}

Figure 1: Geologic sketch map showing major units of El Chichón volcano (after Layer et al., 2009) along with sampling locations from this study.

Figure 2: Color cathodoluminescence (CCL) image for zircon CH14-08 z8 acquired with a TESCAN Vega XMU scanning electron microscope (SEM) and a rainbow CL detector. Zircon grain was selected from the 96 to $250 \mu \mathrm{m}$ size fraction. Rim and core analysis locations are indicated together with U-Th and U-Pb SIMS ages, respectively. The spot with a star indicates

that the core ages is in ${ }^{230} \mathrm{Th} /{ }^{238} \mathrm{U}$ secular equilibrium. Corresponding rare earth element (REE) data for zircon $\mathrm{CH} 14-08 \mathrm{z} 8$ rim and core following grinding and re-polishing after geochronological analysis.

Figure 3: U-Th isochron diagrams distributions for El Chichón samples. Zircon model ages were determined using the isochron slopes defined by zircon (from ion probe analysis using the CAMECA ims 1270 ion microprobe at UCLA) and whole rock (from published data) pairs. Analyses in secular equilibrium are those that overlap the equiline within $2 \sigma$ uncertainties; corresponding $\mathrm{U}-\mathrm{Pb}$ analyses are shown in Fig. 5. 
Figure 4: U-Pb zircon results for El Chichón samples. Analyses were made using the CAMECA ims1270 ion microprobe at UCLA. Xenocrystic domains are interpreted as evidence for crustal contamination of El Chichón magmas assimilating buried basement rocks or sediments. Inset plot shows xenocryst ages in comparison to major regional crust-forming episodes PA (Pan African), GV (Grenville), and RNJ (Rio Negro-Juruena) after Weber et al. (2009).

Figure 5: Probability-density diagrams of U-Th model ages for El Chichón samples. Age distributions are consistent with continuous or frequent pulses of zircon crystallization dating back from near-eruption ages to ca. $84 \mathrm{ka}$. Several samples display common age peaks which suggest major magmatic pulses which predate the established stratigraphic record of the volcano. Note that age axis scaling is linear in relation to the $\left({ }^{230} \mathrm{Th}\right) /\left({ }^{238} \mathrm{U}\right)$ activity ratio to better resolve younger ages, whereas older ages are compressed towards the right end of the plot. Data suspected of overlap onto secular equilibrium cores are omitted.

Figure 6: Summary diagram of all U-Th model ages for El Chichón samples as histogram and probability-density curve in comparison with stages of the Pre-Holocene and Holocene evolution of El Chichón (according to published and unpublished ${ }^{14} \mathrm{C}$ and ${ }^{40} \mathrm{Ar} /{ }^{39} \mathrm{Ar}$ ages summarized in Scolamacchia and Capra, 2015). See comment on non-linear age axis in Fig. 5.

Figure 7: Schematic of the Holocene magma reservoir and the pre-Holocene evolution of a crustally contaminated boundary layer from which xenocrystic zircon with antecrystic overgrowth are recycled. Stage 1 illustrates country rock assimilation, xenocrystic zircon 
resorption, and subsequent overgrowth once the magma reaches zircon saturation (between ca. $84 \mathrm{ka}$ and near-eruption age). Stage 2 initiates with the extraction of high ${ }^{87} \mathrm{Sr} /{ }^{86} \mathrm{Sr}$ partial melt plus antecrystic zircon (sometimes with xenocrystic cores) from the contaminated boundary layer, followed by mixing with low ${ }^{87} \mathrm{Sr} /{ }^{86} \mathrm{Sr}$ recharge magma. During stage 2, plagioclase phenocrysts crystallized within few 100's to 1000's of years before the eruption and record the change in melt composition from more to less contaminated. Sketch is modified from Fig. 2 in Davidson et al. (2007); crystals are not to scale, and no specific geometry of the boundary layer is implicated.

\section{Table Captions}

Table 1: AMS ${ }^{14} \mathrm{C}$ charcoal results with uncalibrated (for comparison with published values) and calibrated (for comparison with other timescales) ages.

Table 2: SIMS U-Th zircon results.

Table 3: SIMS U-Pb zircon results. Bold ages indicate those used for comparison with detrital zircon analyses (Weber et al., 2009). 
Table 1: AMS ${ }^{14} \mathrm{C}$ charcoal results with uncalibrated (for comparison with published values) and calibrated (for comparison with other timescales) ages. Locations see Table 2.

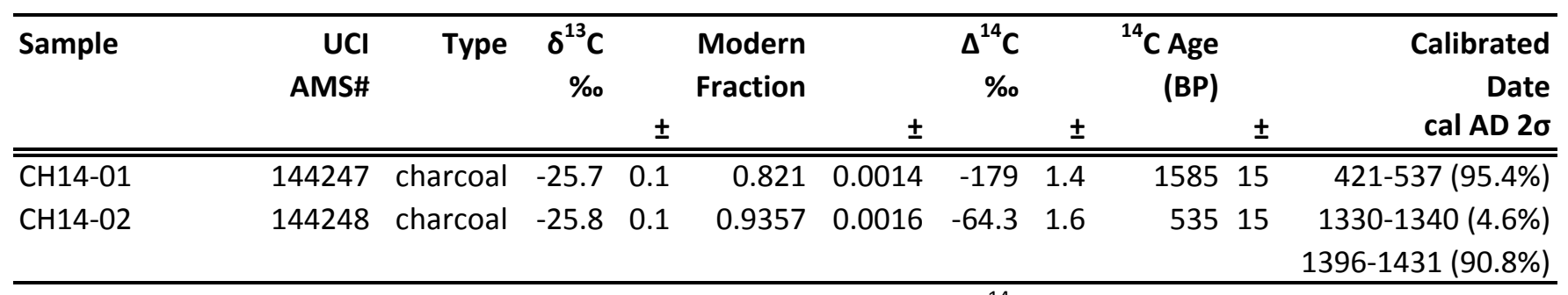

Radiocarbon concentrations are given as fractions of modern standard, $\Delta^{14} \mathrm{C}$, and conventional radiocarbon age, following the conventions of Stuiver and Polach (1977). All results have been corrected for isotopic fractionation according to the conventions of Stuiver and Polach (1977), with $\delta^{13} \mathrm{C}$ values measured on prepared graphite using the spectrometer. These values can differ from $\delta^{13} \mathrm{C}$ of the original material if fractionation occurred during sample graphitization or the AMS measurement, and are not shown. The $\delta^{13} \mathrm{C}$ alues that are from Gas Bench aliquots measured to a precision of $<0.1 \%$ relative to standards traceable to PDB (Craig, 1957), using a Thermo Finnigan Delta Plus stable-isotope mass pectrometer (IRMS)

*Ox Cal v. 4.2 .3 
Table 2: SIMS U-Th zircon results

\begin{tabular}{|c|c|c|c|c|c|c|c|c|c|c|c|c|}
\hline sample & zircon & spot & $\left({ }^{238} \mathrm{U}\right) /\left({ }^{232} \mathrm{Th}\right)$ & \pm & $\left({ }^{230} \mathrm{Th}\right) /\left({ }^{232} \mathrm{Th}\right)$ & \pm & $\mathbf{m}$ & \pm & age (ka) & + & - & $\mathrm{U}(\mathrm{ppm})$ remarks \\
\hline \multicolumn{13}{|c|}{ CH14-05 Lava sample from an autobrecciated dome within the crater of El Chichon (N 17.35935,E -93.2261, $724 \mathrm{~m}$ ) } \\
\hline $\mathrm{CH} 14-05$ & 1 & core & 9.99 & 0.19 & 3.09 & 0.65 & 0.233 & 0.072 & 29.1 & 10.8 & -9.8 & 305 \\
\hline $\mathrm{CH} 14-05$ & 1 & rim & 6.84 & 0.12 & 2.86 & 0.45 & 0.320 & 0.077 & 42.2 & 13.1 & -11.7 & 302 \\
\hline $\mathrm{CH} 14-05$ & 2 & interior & 9.89 & 0.17 & 3.19 & 0.39 & 0.247 & 0.044 & 30.9 & 6.7 & -6.3 & 818 \\
\hline $\mathrm{CH} 14-05$ & 3 & interior & 6.97 & 0.25 & 6.78 & 0.58 & 0.969 & 0.106 & 380 & $\infty$ & -162 & 376 core overlap \\
\hline $\mathrm{CH} 14-05$ & 4 & core & 9.71 & 0.17 & 9.73 & 0.54 & 1.00 & 0.07 & $\infty$ & $\infty$ & $\infty$ & $714 \mathrm{U}-\mathrm{Pb}$ age \\
\hline $\mathrm{CH} 14-05$ & 4 & rim & 9.51 & 0.16 & 4.50 & 0.33 & 0.412 & 0.040 & 57.8 & 7.7 & -7.2 & 868 \\
\hline $\mathrm{CH} 14-05$ & 5 & interior & 5.64 & 0.10 & 2.26 & 0.32 & 0.273 & 0.069 & 34.9 & 10.9 & -9.90 & 396 \\
\hline $\mathrm{CH} 14-05$ & 6 & interior & 4.99 & 0.08 & 2.12 & 0.17 & 0.282 & 0.043 & 36.4 & 7 & -6.6 & 801 \\
\hline $\mathrm{CH} 14-05$ & 7 & interior & 7.24 & 0.12 & 4.34 & 0.37 & 0.536 & 0.060 & 84.1 & 15.5 & -13.5 & 436 \\
\hline $\mathrm{CH} 14-05$ & 9 & interior & 5.53 & 0.10 & 2.25 & 0.24 & 0.277 & 0.053 & 35.6 & 8.5 & -7.9 & 559 \\
\hline $\mathrm{CH} 14-05$ & 10 & core & 5.42 & 0.09 & 1.68 & 0.22 & 0.155 & 0.050 & 18.5 & 6.8 & -6.4 & 503 \\
\hline $\mathrm{CH} 14-05$ & 10 & rim & 5.48 & 0.10 & 1.93 & 0.19 & 0.209 & 0.043 & 25.5 & 5.9 & -5.6 & 955 \\
\hline $\mathrm{CH} 14-05$ & 11 & rim & 11.0 & 0.2 & 10.4 & 0.4 & 0.941 & 0.040 & 298 & 101 & -51.6 & $1840 \mathrm{U}-\mathrm{Pb}$ age \\
\hline $\mathrm{CH} 14-05$ & 11 & core & 13.9 & 0.2 & 5.88 & 0.48 & 0.379 & 0.038 & 52.2 & 7.00 & -6.50 & 681 \\
\hline $\mathrm{CH} 14-05$ & 12 & core & 10.6 & 0.18 & 10.4 & 0.4 & 0.980 & 0.050 & 422 & $\infty$ & -131 & $1210 \mathrm{U}-\mathrm{Pb}$ age \\
\hline $\mathrm{CH} 14-05$ & 12 & rim & 12.7 & 0.2 & 4.73 & 0.50 & 0.319 & 0.043 & 41.9 & 7.1 & -6.6 & 586 \\
\hline $\mathrm{CH} 14-05$ & 13 & core & 4.57 & 0.09 & 2.63 & 0.15 & 0.458 & 0.044 & 66.9 & 9.2 & -8.5 & 1240 \\
\hline $\mathrm{CH} 14-05$ & 13 & rim & 10.9 & 0.2 & 5.02 & 0.24 & 0.407 & 0.025 & 56.8 & 4.8 & -4.6 & 1720 \\
\hline \multicolumn{13}{|c|}{ CH14-08 Composite pumice (10-20 cm in diameter) from pyroclastic flow deposit overlain by surge and fall-out deposits ( $\mathrm{N} 17.36411, \mathrm{E}-93.2009,677 \mathrm{~m})$} \\
\hline $\mathrm{CH} 14-08$ & 1 & interior & 9.87 & 0.17 & 3.93 & 0.42 & 0.331 & 0.048 & 43.8 & 8.2 & -7.6 & 431 \\
\hline $\mathrm{CH} 14-08$ & 2 & rim & 7.04 & 0.12 & 2.71 & 0.23 & 0.284 & 0.039 & 36.6 & 6.1 & -5.8 & 719 \\
\hline $\mathrm{CH} 14-08$ & 2 & core & 2.17 & 0.04 & 2.41 & 0.18 & 1.21 & 0.17 & $\infty$ & $\infty$ & $\infty$ & 412 \\
\hline $\mathrm{CH} 14-08$ & 3 & interior & 10.1 & 0.2 & 3.06 & 0.34 & 0.227 & 0.038 & 28.3 & 5.5 & -5.2 & 464 \\
\hline $\mathrm{CH} 14-08$ & 4 & interior & 6.68 & 0.12 & 2.61 & 0.21 & 0.285 & 0.038 & 36.4 & 6 & -5.7 & 770 \\
\hline $\mathrm{CH} 14-08$ & 5 & interior & 5.48 & 0.11 & 1.77 & 0.28 & 0.173 & 0.063 & 20.7 & 8.5 & -7.8 & 441 \\
\hline $\mathrm{CH} 14-08$ & 6 & interior & 7.50 & 0.13 & 3.05 & 0.23 & 0.316 & 0.036 & 41.6 & 6 & -5.7 & 855 \\
\hline $\mathrm{CH} 14-08$ & 7 & interior & 8.01 & 0.14 & 3.99 & 0.26 & 0.427 & 0.038 & 60.9 & 7.6 & -7.1 & 1100 \\
\hline $\mathrm{CH} 14-08$ & 8 & core & 9.51 & 0.17 & 10.3 & 0.7 & 1.09 & 0.09 & $\infty$ & $\infty$ & $\infty$ & 602 U-Pb age \\
\hline $\mathrm{CH} 14-08$ & 8 & rim & 8.59 & 0.19 & 2.89 & 0.27 & 0.250 & 0.036 & 31.3 & 5.4 & -5.2 & 560 \\
\hline $\mathrm{CH} 14-08$ & 10 & core & 14.8 & 0.4 & 16.0 & 0.78 & 1.09 & 0.06 & $\infty$ & $\infty$ & $\infty$ & $551 \mathrm{U}-\mathrm{Pb}$ age \\
\hline $\mathrm{CH} 14-08$ & 10 & rim & 8.83 & 0.15 & 4.05 & 0.56 & 0.390 & 0.072 & 54.0 & 13.7 & -12.2 & 325 \\
\hline $\mathrm{CH} 14-08$ & 12 & core & 7.61 & 0.18 & 8.17 & 0.59 & 1.09 & 0.09 & $\infty$ & $\infty$ & $\infty$ & 399 U-Pb age \\
\hline $\mathrm{CH} 14-08$ & 12 & rim & 15.0 & 0.3 & 15.0 & 1.8 & 1.00 & 0.13 & 734 & $\infty$ & -511 & 345 core overlap \\
\hline $\mathrm{CH} 14-08$ & 13 & interior & 4.22 & 0.07 & 1.26 & 0.07 & 0.083 & 0.022 & 9.3 & 2.7 & -2.7 & 1990 \\
\hline \multicolumn{13}{|c|}{ CH14-09 Composite yellow pumice clasts (max. $10 \mathrm{~cm}$ in diameter) from fall-out deposit (N 17.34828, E -93.1315, 583 m) } \\
\hline $\mathrm{CH} 14-09$ & 1 & interior & 6.34 & 0.11 & 2.47 & 0.2 & 0.276 & 0.038 & 35.2 & 5.9 & -5.6 & 672 \\
\hline CH14-09 & 2 & core & 6.49 & 0.13 & 2.47 & 0.22 & 0.269 & 0.041 & 34.2 & 6.2 & -5.8 & 593 \\
\hline CH14-09 & 2 & rim & 4.37 & 0.07 & 1.17 & 0.13 & 0.052 & 0.039 & 5.8 & 4.7 & -4.5 & 709 \\
\hline CH14-09 & 3 & interior & 11.3 & 0.2 & 5.38 & 0.34 & 0.426 & 0.034 & 60.9 & 6.8 & -6.4 & 929 \\
\hline $\mathrm{CH} 14-09$ & 4 & interior & 4.21 & 0.1 & 2.15 & 0.33 & 0.360 & 0.104 & 48.7 & 19.5 & -16.6 & 297 \\
\hline $\mathrm{CH} 14-09$ & 5 & core & 8.84 & 0.18 & 11.4 & 1.1 & 1.33 & 0.14 & $\infty$ & $\infty$ & $\infty$ & 580 \\
\hline $\mathrm{CH} 14-09$ & 5 & rim & 6.90 & 0.13 & 2.42 & 0.18 & 0.242 & 0.031 & 30.3 & 4.7 & -4.5 & 947 \\
\hline $\mathrm{CH} 14-09$ & 6 & interior & 3.37 & 0.06 & 1.29 & 0.08 & 0.125 & 0.034 & 14.8 & 4.4 & -4.3 & 1510 \\
\hline $\mathrm{CH} 14-09$ & 7 & interior & 5.49 & 0.1 & 2.01 & 0.33 & 0.226 & 0.074 & 28.1 & 10.9 & -9.90 & 427 \\
\hline $\mathrm{CH} 14-09$ & 8 & interior & 12.3 & 0.2 & 5.67 & 0.53 & 0.414 & 0.048 & 58.5 & 9.3 & -8.6 & 659 \\
\hline CH14-09 & 9 & core & 9.71 & 0.16 & 4.12 & 0.33 & 0.359 & 0.039 & 48.5 & 6.8 & -6.4 & 906 \\
\hline CH14-09 & 9 & rim & 13.9 & 0.3 & 5.62 & 0.44 & 0.359 & 0.035 & 48.3 & 6.1 & -5.8 & 868 \\
\hline $\mathrm{CH} 14-09$ & 10 & interior & 6.39 & 0.15 & 5.52 & 0.78 & 0.840 & 0.147 & 200 & 268 & -70.9 & $593 \mathrm{U}-\mathrm{Pb}$ age \\
\hline CH14-09 & 11 & interior & 7.72 & 0.13 & 2.89 & 0.21 & 0.282 & 0.032 & 36.2 & 4.9 & -4.6 & 1010 \\
\hline CH14-09 & 12 & interior & 6.00 & 0.1 & 2.59 & 0.23 & 0.319 & 0.047 & 42.0 & 7.8 & -7.3 & 702 \\
\hline $\mathrm{CH} 14-09$ & 13 & interior & 5.08 & 0.09 & 1.87 & 0.13 & 0.215 & 0.032 & 26.5 & 4.5 & -4.4 & 1840 \\
\hline $\mathrm{CH} 14-09$ & 14 & interior & 5.38 & 0.09 & 1.46 & 0.14 & 0.107 & 0.032 & 12.3 & 3.9 & -3.8 & 947 \\
\hline \multicolumn{13}{|c|}{ CH14-01 Composite pumice (10-15 cm in diameter) from base of pyroclastic-flow deposit (N 17.36320, E -93.21140, $724 \mathrm{~m}$ ) } \\
\hline $\mathrm{CH} 14-01$ & 1 & rim & 5.05 & 0.05 & 1.62 & 0.39 & 0.156 & 0.095 & 18.4 & 13.0 & -11.6 & 506 \\
\hline $\mathrm{CH} 14-01$ & 2 & rim & 8.32 & 0.07 & 3.13 & 0.31 & 0.292 & 0.042 & 37.7 & 6.7 & -6.3 & 2300 \\
\hline $\mathrm{CH} 14-01$ & 3 & rim & 13.1 & 0.13 & 5.66 & 0.34 & 0.387 & 0.029 & 53.3 & 5.2 & -5.00 & 4280 \\
\hline $\mathrm{CH} 14-01$ & 4 & core & 8.95 & 0.09 & 5.23 & 0.63 & 0.532 & 0.079 & 82.9 & 20.3 & -17.1 & 836 \\
\hline $\mathrm{CH} 14-01$ & 4 & rim & 6.74 & 0.06 & 2.12 & 0.36 & 0.196 & 0.063 & 23.8 & 8.9 & -8.2 & 942 \\
\hline $\mathrm{CH} 14-01$ & 5 & rim & 7.04 & 0.07 & 1.01 & 0.22 & 0.002 & 0.036 & 0.2 & 4.03 & -3.88 & 905 \\
\hline $\mathrm{CH} 14-01$ & 6 & rim & 6.85 & 0.06 & 1.86 & 0.28 & 0.147 & 0.047 & 17.4 & 6.2 & -5.9 & 1020 \\
\hline $\mathrm{CH} 14-01$ & 7 & rim & 7.03 & 0.07 & 2.74 & 0.26 & 0.290 & 0.043 & 37.4 & 6.8 & -6.4 & 1880 \\
\hline $\mathrm{CH} 14-01$ & 8 & rim & 10.3 & 0.1 & 3.20 & 0.37 & 0.238 & 0.040 & 29.7 & 5.9 & -5.6 & 1660 \\
\hline $\mathrm{CH} 14-01$ & 10 & rim & 6.04 & 0.06 & 1.98 & 0.19 & 0.197 & 0.039 & 23.9 & 5.4 & -5.1 & 2190 \\
\hline
\end{tabular}


Table 3: SIMS U-Pb zircon results. Bold ages indicate those used for comparison with detrital zircon analyses (Weber et al., 2009)

\begin{tabular}{|c|c|c|c|c|c|c|c|c|c|c|c|c|c|c|c|c|c|c|c|}
\hline \multirow{2}{*}{$\begin{array}{l}\text { sample } \\
\text { CH14-05 }\end{array}$} & \multirow{2}{*}{$\begin{array}{r}\text { zircon } \\
\\
4\end{array}$} & \multicolumn{2}{|c|}{$\begin{array}{l}\text { spot Age } \\
{ }^{206} \mathrm{~Pb} /{ }^{238} \mathrm{U}\end{array}$} & \multicolumn{2}{|c|}{$\begin{array}{c}\text { Age } \\
\pm{ }^{207} \mathrm{~Pb} /{ }^{235} \mathrm{U}\end{array}$} & \multicolumn{2}{|c|}{$\begin{array}{c}\text { Age } \\
\pm{ }^{207} \mathrm{~Pb} /{ }^{206} \mathrm{~Pb}\end{array}$} & $\begin{array}{r}\% \text { Radi } \\
\pm 206 \mathrm{~Pb}\end{array}$ & enic & ${ }^{206} \mathrm{~Pb} * /^{238} \mathrm{U}$ & \multicolumn{2}{|c|}{$\pm{ }^{207} \mathrm{~Pb} * /{ }^{235} \mathrm{U}$} & \multicolumn{2}{|c|}{$\pm{ }^{207} \mathrm{~Pb} * /{ }^{206} \mathrm{~Pb}$} & \multicolumn{2}{|r|}{$\begin{array}{l}\text { Correlation } \\
\pm \text { of Concordia } \\
\text { Ellipses } \\
\end{array}$} & $\begin{array}{l}\mathrm{U} \\
\mathrm{ppm}\end{array}$ & $\begin{array}{l}\text { Th/ } \\
\text { U }\end{array}$ & $\begin{array}{l}\mathrm{UO} / \mathrm{Pb} \text { corr } \\
\mathrm{U}\end{array}$ \\
\hline & & core & 841 & 20 & 883 & 17.3 & 991 & 29 & 99.6 & 0.139 & 0.003 & 1.39 & 0.04 & 0.0722 & 0.0010 & 0.88 & 217 & 0.36 & $8.79\left({ }^{204} \mathrm{~Pb}\right)$ \\
\hline $\mathrm{CH} 14-05$ & 11 & rim & 65.5 & 2.0 & 76.57 & 8.27 & 437 & 222 & 98.2 & 0.0102 & 0.0003 & 0.0783 & 0.0088 & 0.0556 & 0.0056 & 0.51 & 281 & 0.25 & $8.75\left({ }^{204} \mathrm{~Pb}\right)$ \\
\hline $\mathrm{CH} 14-05$ & 12 & core & 954 & 22 & 939 & 21 & 903 & 50 & 98.6 & 0.160 & 0.004 & 1.52 & 0.05 & 0.0691 & 0.0017 & 0.71 & 106 & 0.23 & $9.04\left({ }^{204} \mathrm{~Pb}\right)$ \\
\hline $\mathrm{CH} 14-08$ & 8 & core & 599 & 13 & 709 & 21 & 1076 & 66 & 96.7 & 0.0974 & 0.0023 & 1.01 & 0.04 & 0.0753 & 0.0025 & 0.62 & 170 & 0.24 & $9.21\left({ }^{204} \mathrm{~Pb}\right)$ \\
\hline $\mathrm{CH} 14-08$ & 10 & core & 290 & 9 & 287 & 27 & 264 & 216 & 96.4 & 0.0460 & 0.0015 & 0.327 & 0.035 & 0.0515 & 0.0048 & 0.53 & 76 & 0.65 & $8.46\left({ }^{208} \mathrm{~Pb}\right)$ \\
\hline $\mathrm{CH} 14-08$ & 12 & core & 962 & 25 & 929 & 27 & 851 & 63 & 98.0 & 0.161 & 0.005 & 1.50 & 0.07 & 0.0674 & 0.0020 & 0.73 & 126 & 0.32 & $8.45\left({ }^{204} \mathrm{~Pb}\right)$ \\
\hline CH14-09 & 10 & core & 516 & 14 & 501 & 26 & 433 & 121 & 98.7 & 0.0834 & 0.0023 & 0.638 & 0.042 & 0.0555 & 0.0030 & 0.60 & 95 & 0.60 & $9.12\left({ }^{204} \mathrm{~Pb}\right)$ \\
\hline $\mathrm{CH} 14-06$ & 4 & core & 315 & 6 & 335 & 11 & 474 & 97 & 100 & 0.0502 & 0.0011 & 0.391 & 0.015 & 0.0566 & 0.0025 & -0.06 & 395 & 0.33 & $6.72\left({ }^{204} \mathrm{~Pb}\right)$ \\
\hline $\mathrm{CH} 14-06$ & 7 & core & 460 & 9 & 449 & 17 & 391 & 94 & 99.6 & 0.0740 & 0.0015 & 0.556 & 0.026 & 0.0545 & 0.0023 & 0.46 & 617 & 0.32 & $6.78\left({ }^{204} \mathrm{~Pb}\right)$ \\
\hline $\mathrm{CH} 14-06$ & 9 & core & 466 & 16 & 487 & 22 & 585 & 89 & 99.4 & 0.0750 & 0.0027 & 0.615 & 0.035 & 0.0595 & 0.0024 & 0.70 & 678 & 0.26 & $6.50\left({ }^{204} \mathrm{~Pb}\right)$ \\
\hline CH14-06 & 13 & core & 324 & 8 & 258 & 45 b.d. & & b.d. & 98.0 & 0.0515 & 0.0013 & 0.289 & 0.057 & 0.0408 & 0.0075 & 0.53 & 251 & 1.23 & $6.58\left({ }^{204} \mathrm{~Pb}\right)$ \\
\hline $\mathrm{CH} 14-06$ & 14 & core & 126 & 3 & 150 & 7 & 552 & 116 & 99.5 & 0.0197 & 0.0004 & 0.159 & 0.008 & 0.0586 & 0.0031 & 0.19 & 1226 & 0.26 & $6.89\left({ }^{204} \mathrm{~Pb}\right)$ \\
\hline $\mathrm{CH} 14-04$ & 6 & core & 269 & 6 & 354 & 19 & 962 & 110 & 99.5 & 0.0426 & 0.0009 & 0.418 & 0.027 & 0.0712 & 0.0038 & 0.60 & 722 & 0.60 & $6.41\left({ }^{204} \mathrm{~Pb}\right)$ \\
\hline $\mathrm{CH} 14-02$ & 1 & core & 437 & 9 & 412 & 22 & 276 & 138 & 98.6 & 0.0701 & 0.0015 & 0.500 & 0.032 & 0.0518 & 0.0031 & 0.31 & 748 & 0.45 & $6.83\left({ }^{204} \mathrm{~Pb}\right)$ \\
\hline $\mathrm{CH} 14-02$ & 8 & core & 72.2 & 1.6 & 111 & 5 & 1051 & 79 & 99.9 & 0.0113 & 0.0002 & 0.116 & 0.005 & 0.0744 & 0.0029 & 0.47 & 1224 & 0.33 & $7.08\left({ }^{204} \mathrm{~Pb}\right)$ \\
\hline $\mathrm{CH} 14-02$ & 15 & core & 1492 & 55 & 1666 & 38 & 1894 & 37 & 100 & 0.260 & 0.011 & 4.16 & 0.20 & 0.116 & 0.002 & 0.90 & 184 & 1.55 & $6.78\left({ }^{204} \mathrm{~Pb}\right)$ \\
\hline $\mathrm{CH} 14-02$ & 16 & core & 956 & 38 & 973 & 41 & 1012 & 104 & 99.7 & 0.160 & 0.007 & 1.61 & 0.11 & 0.0729 & 0.0037 & 0.63 & 106 & 0.38 & $6.84\left({ }^{204} \mathrm{~Pb}\right)$ \\
\hline $\mathrm{CH} 14-01$ & 4 & core & 1266 & 39 & 1399 & 33 & 1608 & 38 & 99.5 & 0.217 & 0.007 & 2.97 & 0.13 & 0.0991 & 0.0020 & 0.88 & 248 & 0.17 & $6.78\left({ }^{204} \mathrm{~Pb}\right)$ \\
\hline CH14-01 & 8 & core & 598 & 24 & 595 & 38 & 586 & 145 & 99.7 & 0.0971 & 0.0041 & 0.797 & 0.068 & 0.0595 & 0.0040 & 0.63 & 124 & 0.73 & $6.84\left({ }^{204} \mathrm{~Pb}\right)$ \\
\hline $\mathrm{CH} 14-01$ & 11 & core & 1335 & 42 & 1478 & 40 & 1690 & 72 & 98.9 & 0.230 & 0.008 & 3.29 & 0.17 & 0.104 & 0.004 & 0.65 & 135 & 0.95 & $7.03\left({ }^{204} \mathrm{~Pb}\right)$ \\
\hline CH14-01 & 13 & core & 382 & 12 & 385 & 32 & 404 & 213 & 99.4 & 0.0611 & 0.0020 & 0.461 & 0.045 & 0.0548 & 0.0052 & 0.26 & 193 & 1.06 & $6.75\left({ }^{204} \mathrm{~Pb}\right)$ \\
\hline $\mathrm{CH} 14-01$ & 15 & core & 352 & 11 & 314 & 59 & 39 & 500 & 98.4 & 0.0561 & 0.0018 & 0.362 & 0.080 & 0.0468 & 0.0098 & 0.40 & 104 & 0.60 & $6.74\left({ }^{204} \mathrm{~Pb}\right)$ \\
\hline
\end{tabular}

decay constants used: $\lambda_{232}: 4.9475 \cdot 10^{-11} \mathrm{a}^{-1} ; \lambda_{238}: 1.55125 \cdot 10^{-10} \mathrm{a}^{-1}$

common $\mathrm{Pb}$ correction: ${ }^{206} \mathrm{~Pb} /{ }^{204} \mathrm{~Pb}=18.86,{ }^{207} \mathrm{~Pb} /{ }^{204} \mathrm{~Pb}=15.62,{ }^{208} \mathrm{~Pb} /{ }^{204} \mathrm{~Pb}=38.43$

$\mathrm{UO}^{+} / \mathrm{U}^{+}$vs. $\mathrm{Pb} / \mathrm{U}^{+}$calibration slope $=0.5-9.53 \pm 0.18$; external reproducibility of $\mathrm{AS3}{ }^{206} \mathrm{~Pb} /{ }^{238} \mathrm{U}$ age $=1.8 \%(\mathrm{n}=5 ;$ Aug 2014$) ; 1.15-3.37 \pm 0.04 ;$ external reproducibility of $\mathrm{AS3}{ }^{206} \mathrm{~Pb} /{ }^{238} \mathrm{U}$ age $=1.1 \%(\mathrm{n}=8 ;$ Jan 2015$)$ $\mathrm{Th}^{+} / \mathrm{U}^{+}$relative sensitivity 0.957 (Aug 2014) and 1.01 (Jan 2015)

$\mathrm{U}$ ppm from $\mathrm{U} / \mathrm{Zr}_{2} \mathrm{O}_{2}$ (Aug 2014) and $\mathrm{U} /{ }^{94} \mathrm{Zr}_{2} \mathrm{O}$ (Jan 2015) relative to 91500 zircon with $81.2 \mathrm{ppm} \mathrm{U}$

bold indicates preferred age 


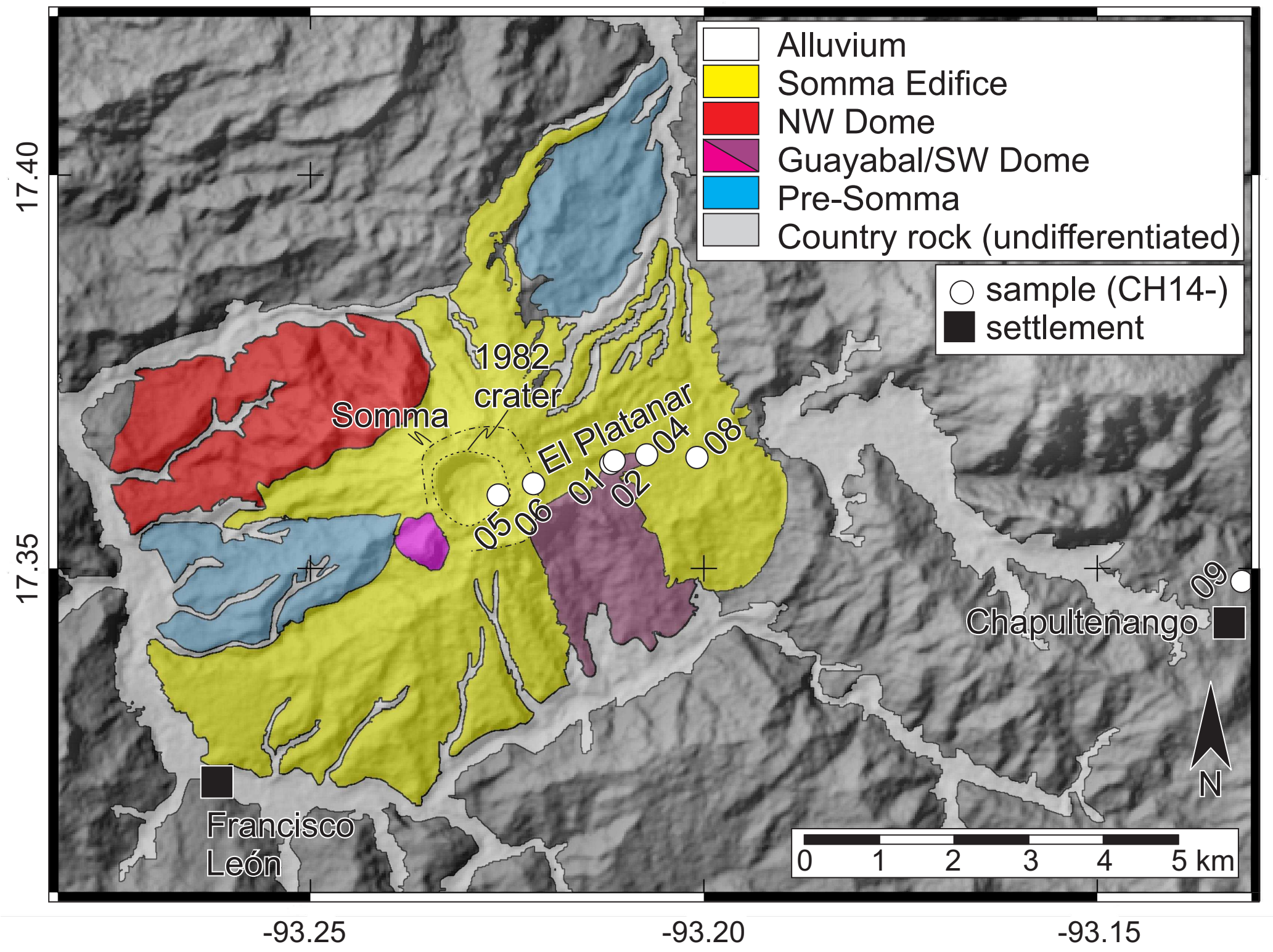

Fig. 1 Pack et al. 


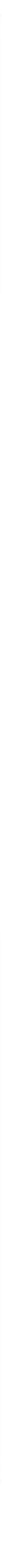

Fig. 1 Pack et al. 
Figure 2

\section{A}

\section{$1076 \pm 66 \mathrm{Ma}$}

$31.3 \pm 5.3 \mathrm{ka}$

\section{$10 \mu \mathrm{m}$}

CH14-08 z8

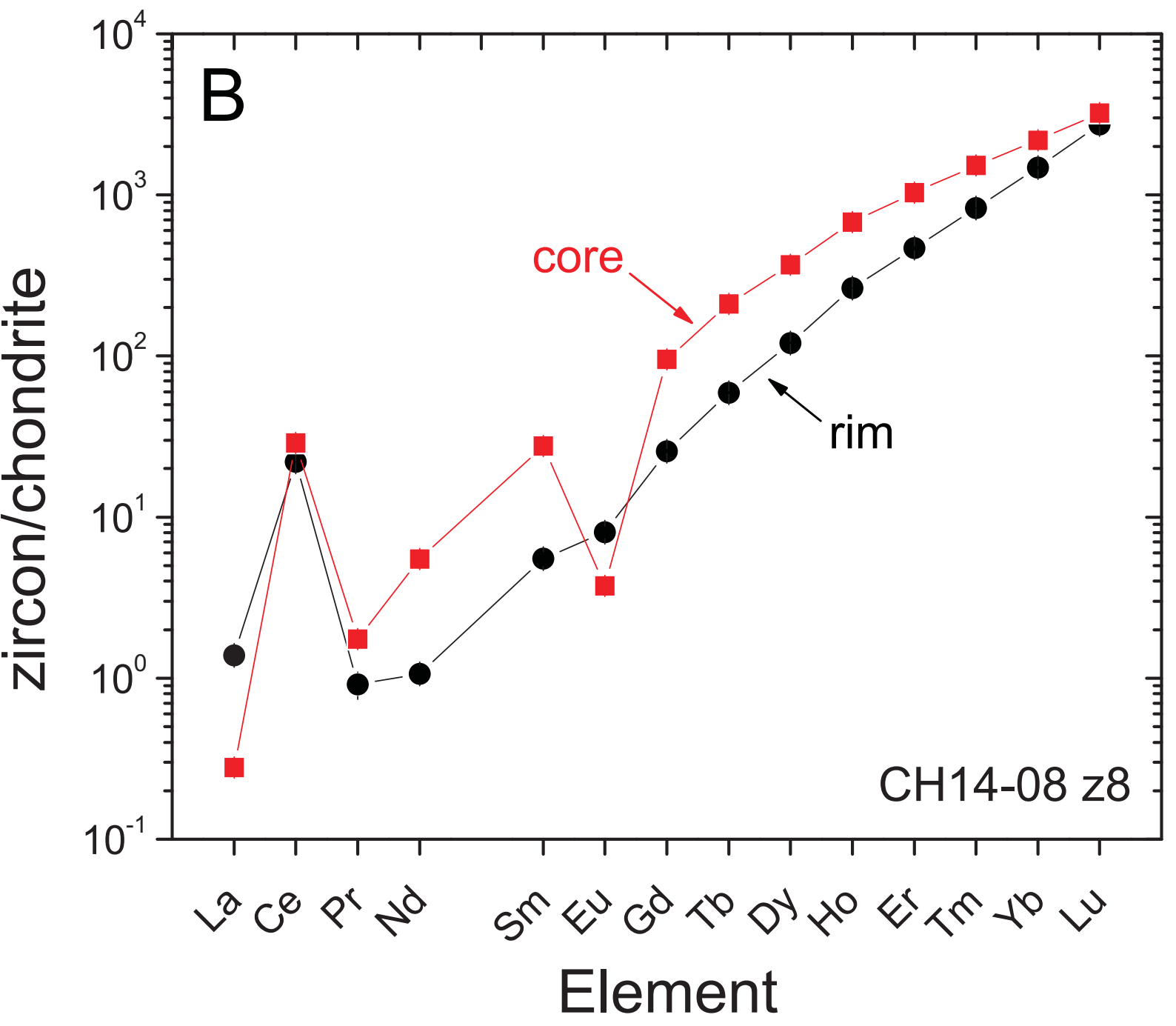

Fig. 2 Pack et al. 

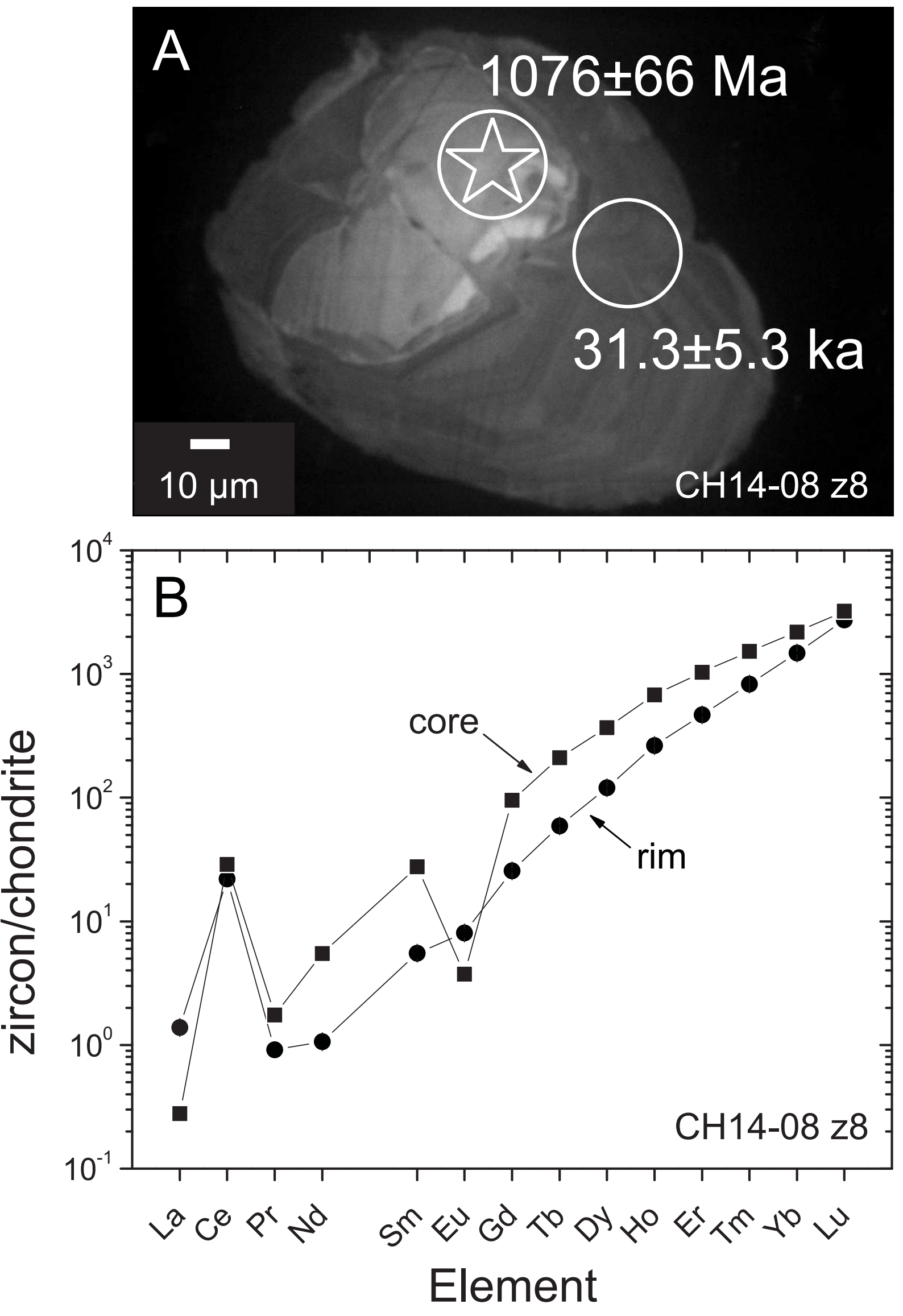

Fig. 2 Pack et al. 
Figure 38

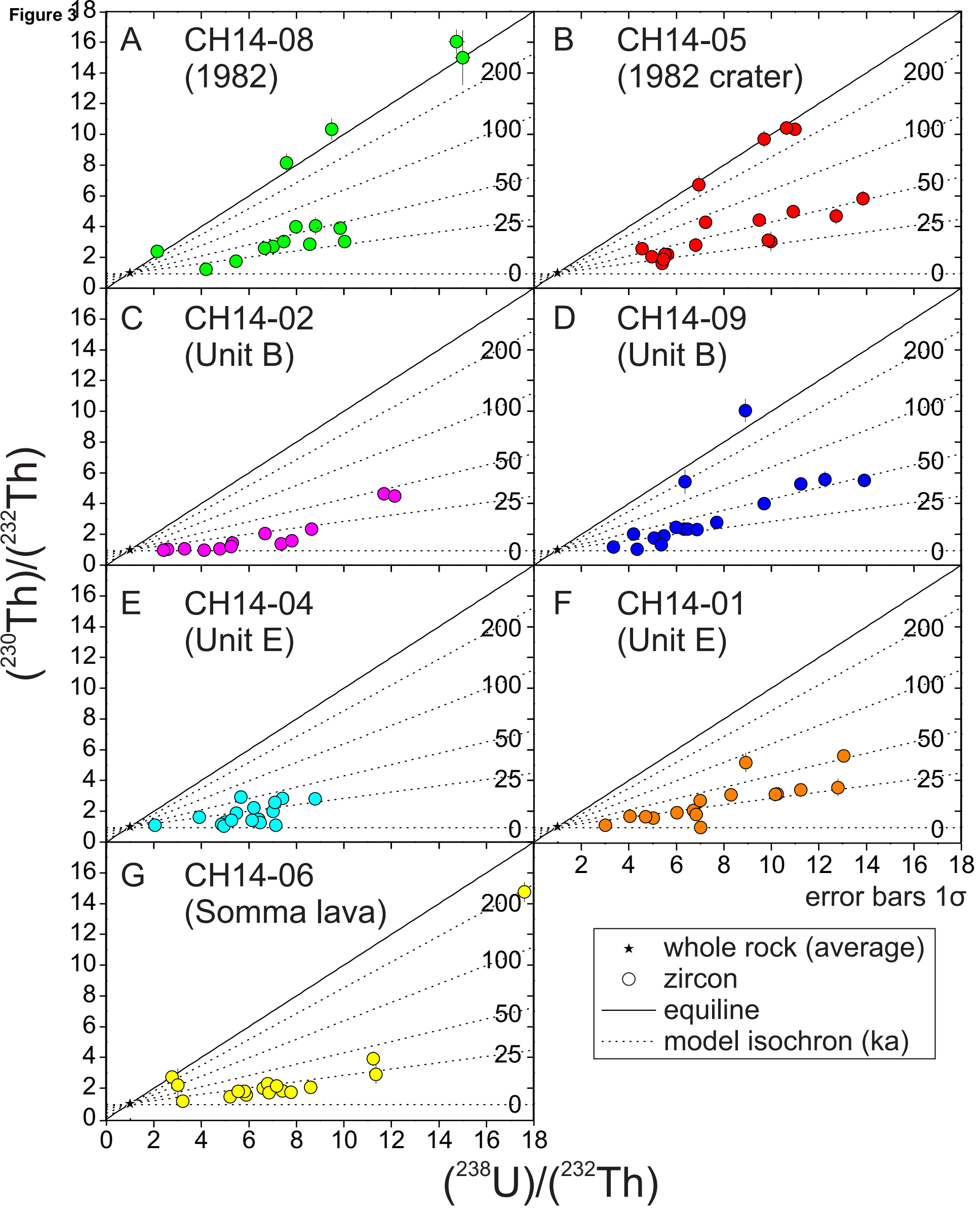

Fig. 3 Pack et al. 


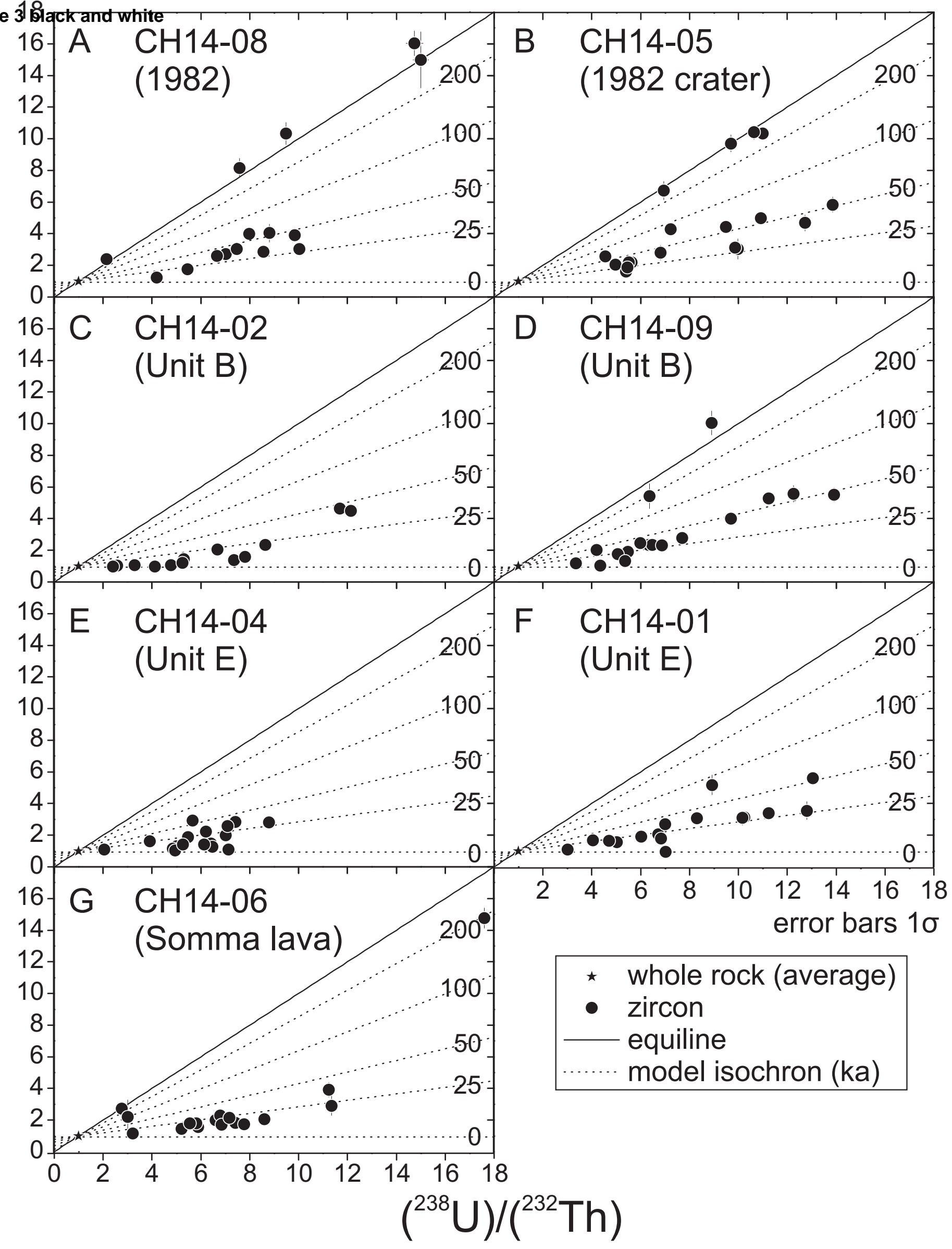

Fig. 3 Pack et al. 
Figure 40.30

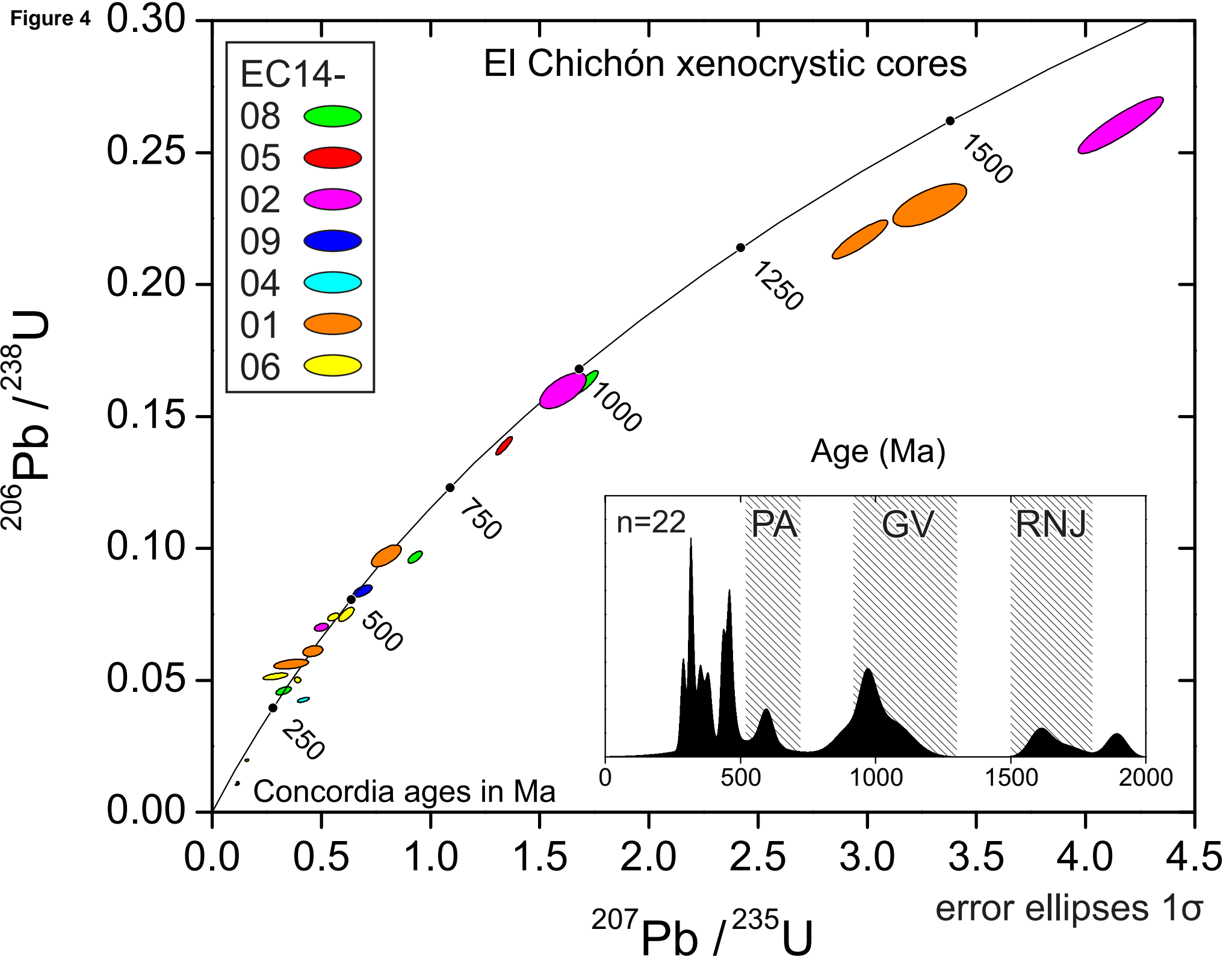

Fig. 4 Pack et al. 
Figure 4 b@çßAd white

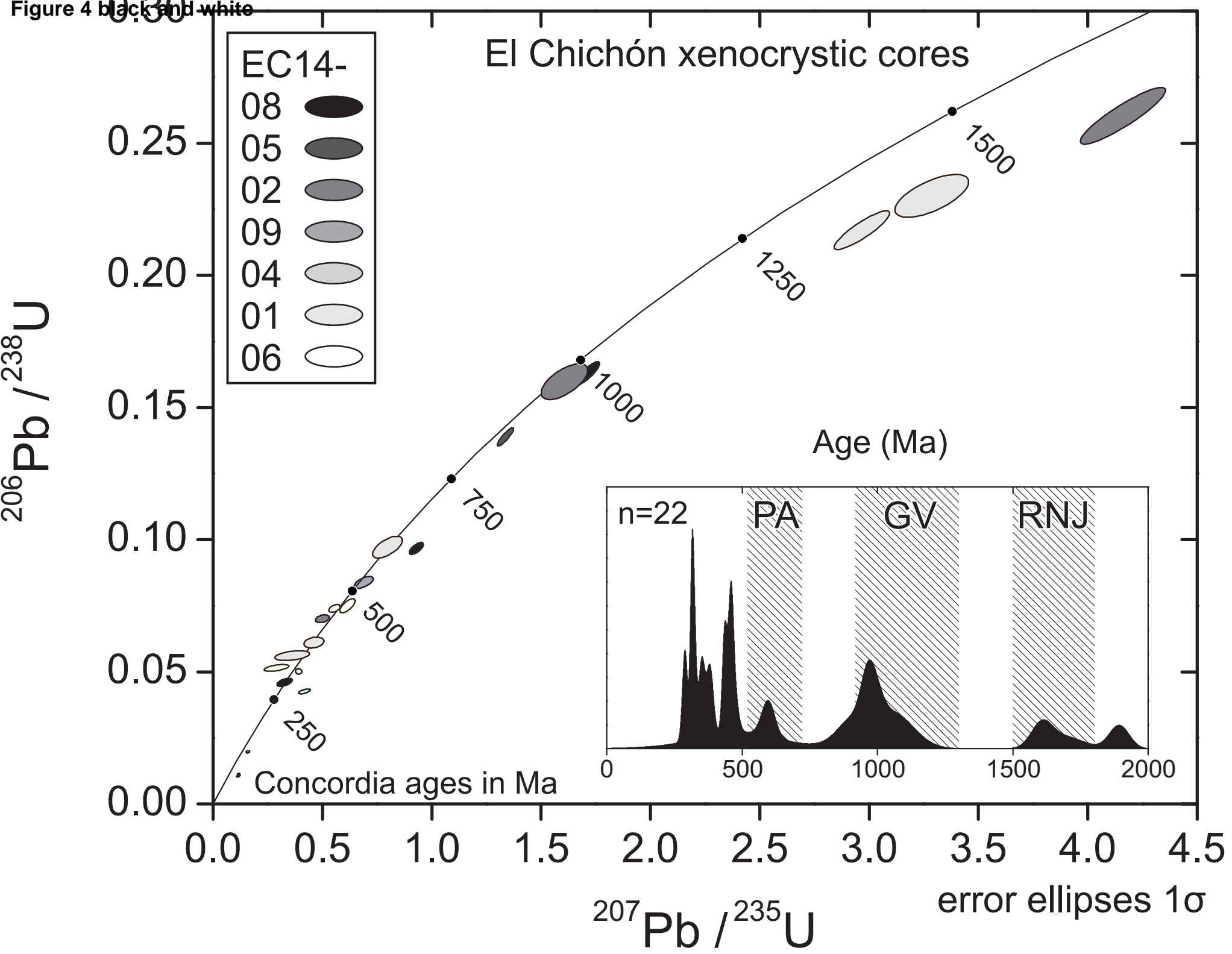

Fig. 4 Pack et al. 
Figure 5

CH14-08

B

(1982)

- $\mathrm{CH} 14-05$

(1982 crater)

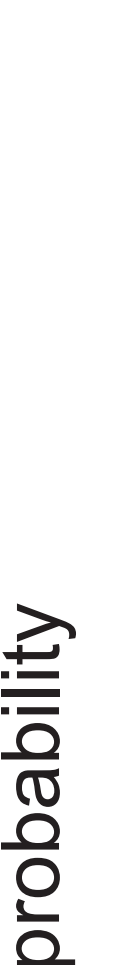

$\frac{\mathbb{d}}{\frac{\mathbb{d}}{\mathbb{Q}}}$

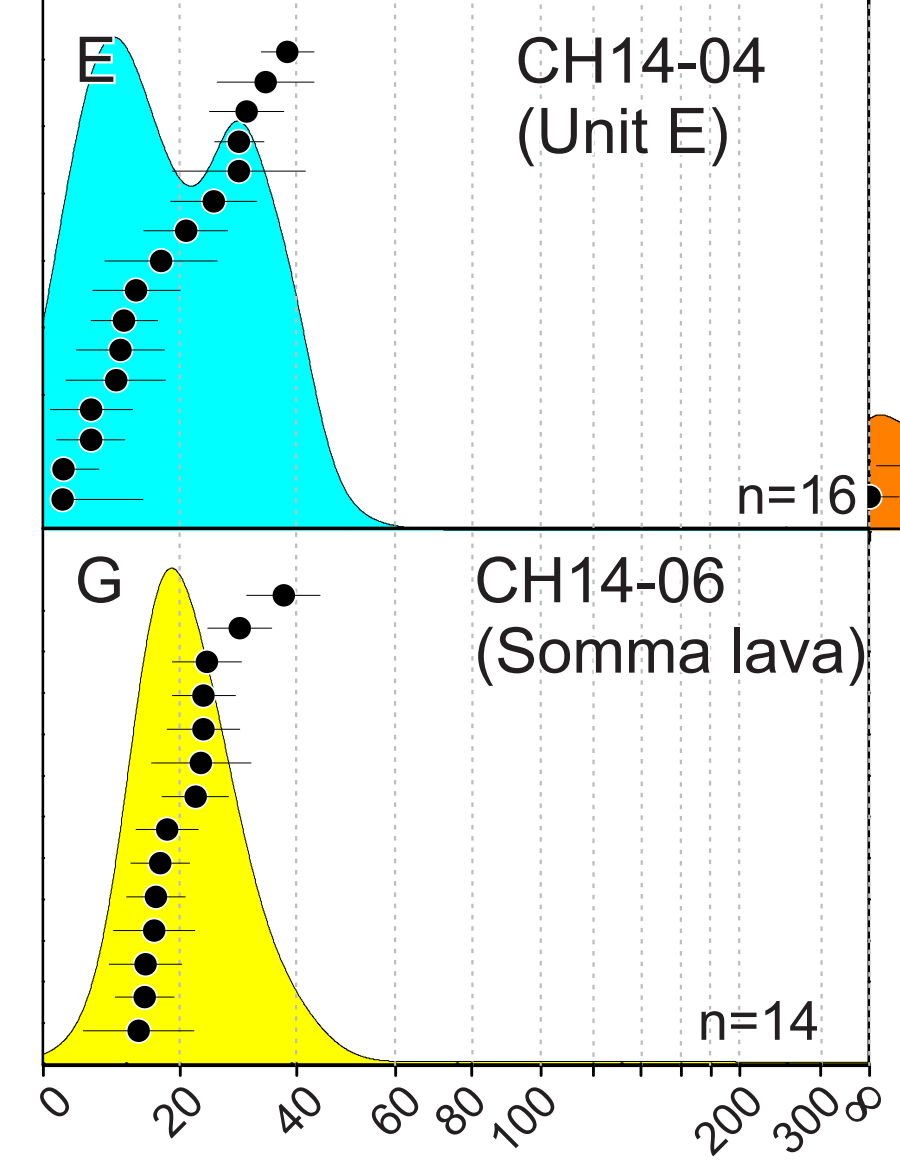

$\left({ }^{230} \mathrm{Th}\right) /\left({ }^{238} \mathrm{U}\right)$ model age (ka)

Fig. 5 Pack et al. 
Figure 5 glack and white

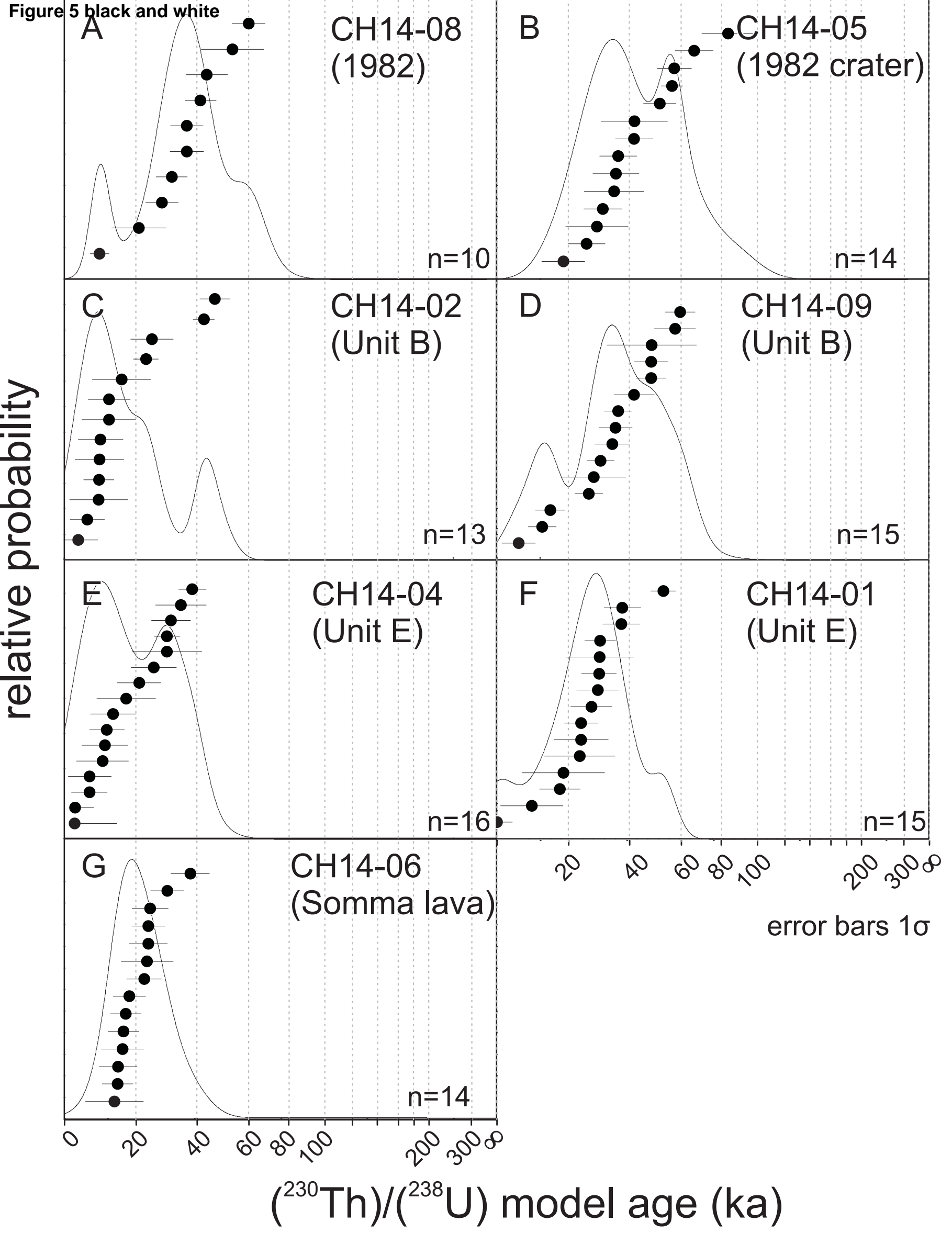

Fig. 5 Pack et al. 


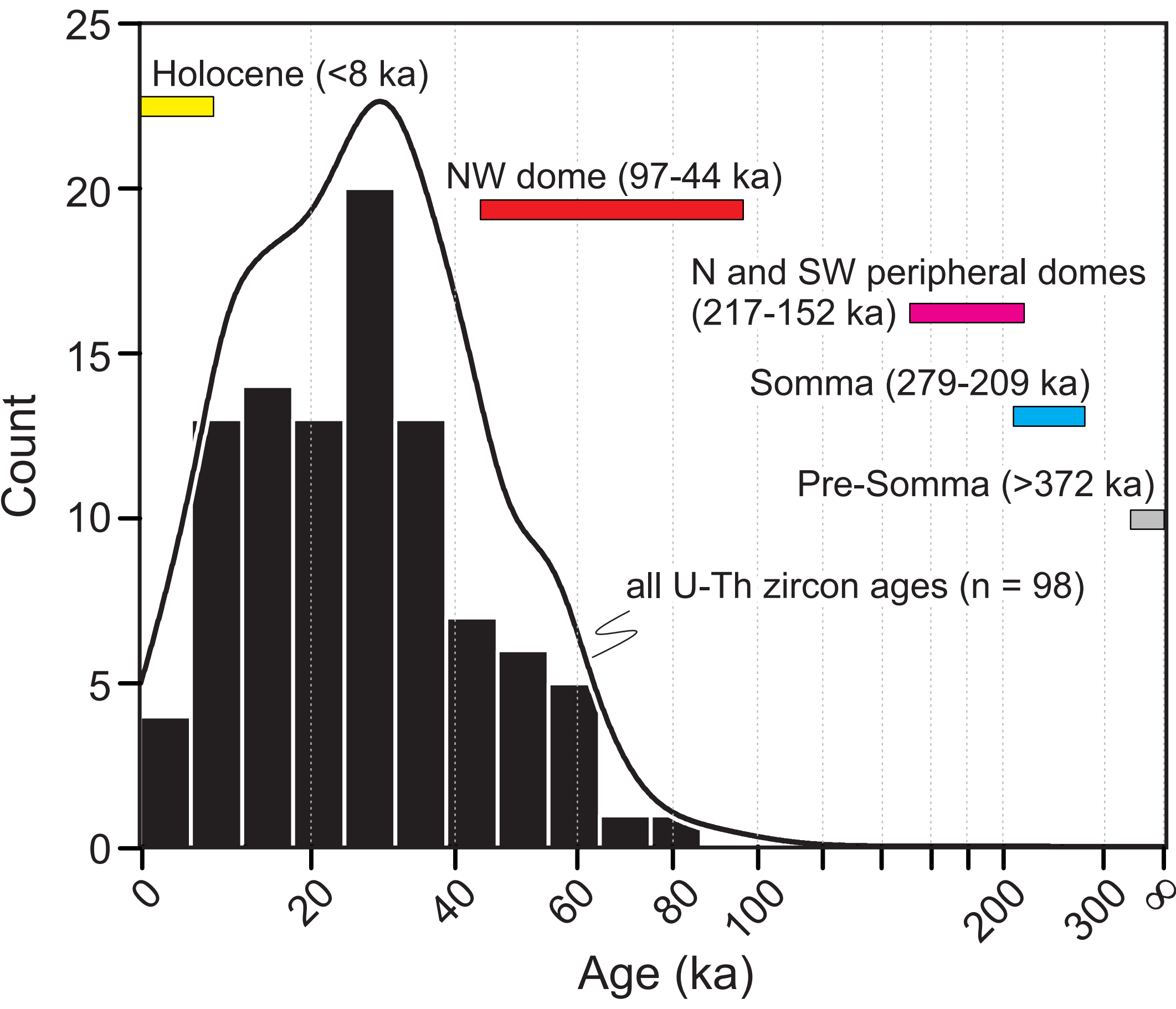

Fig. 6 Pack et al. 


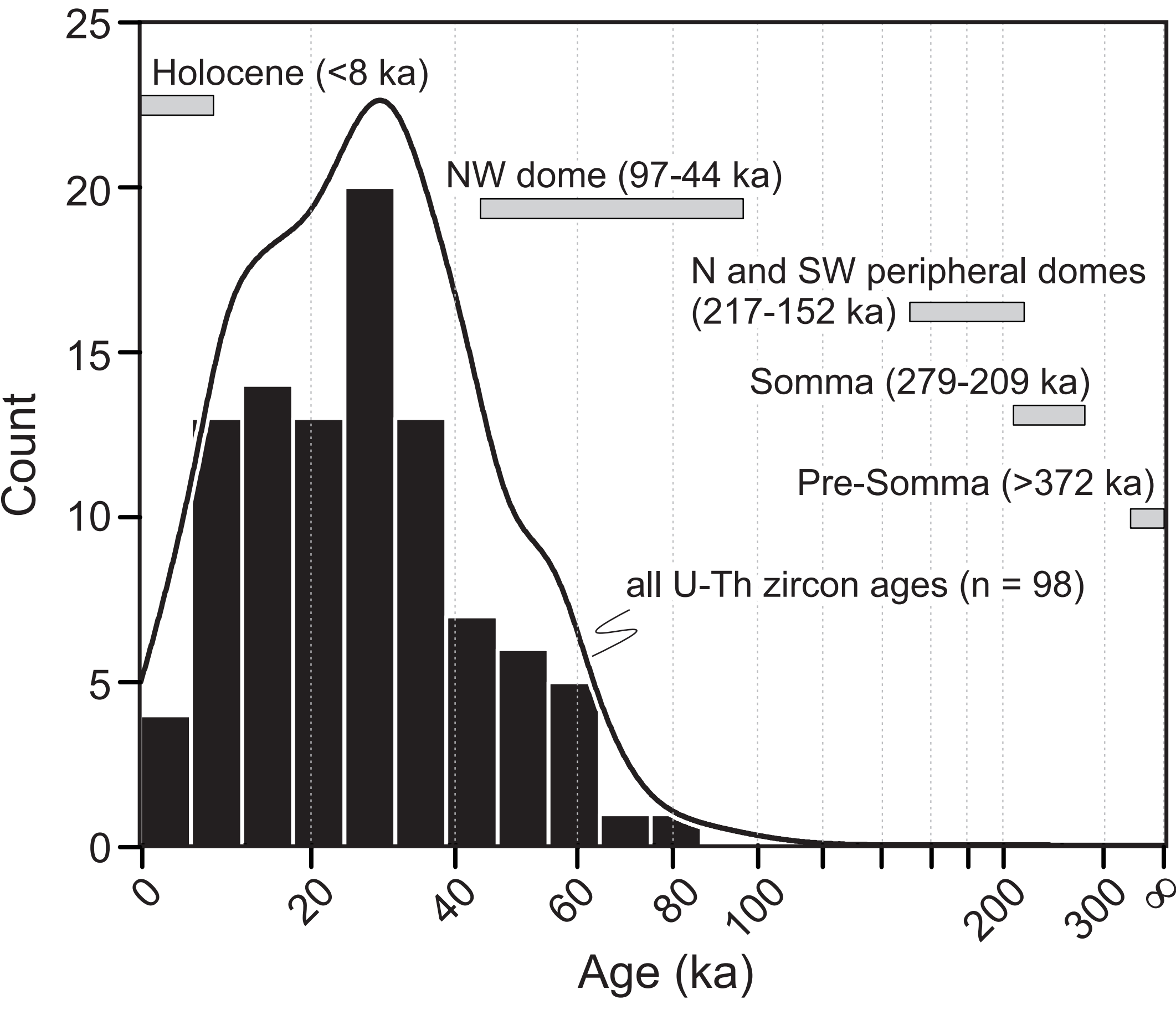

Fig. 6 Pack et al. 


$$
1
$$


Figure 7 blaqk and white
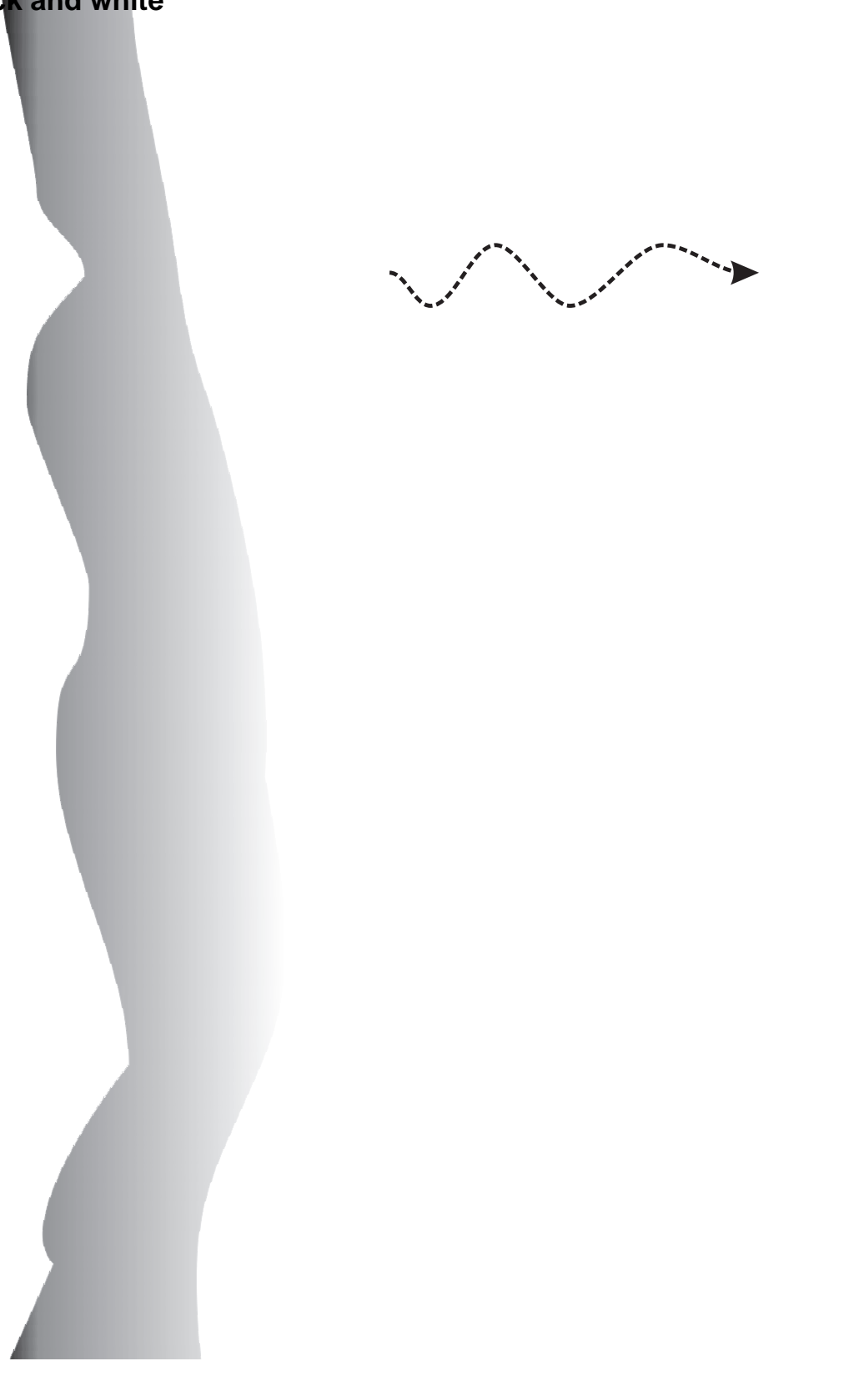